The University of Maine

DigitalCommons@UMaine

Publications

Senator George J. Mitchell Center for Sustainability

Solutions

2012

\title{
Critical Habitat and the Challenge of Regulating Small Harms.
}

Dave Owen

University of Maine School of Law

Follow this and additional works at: https://digitalcommons.library.umaine.edu/ mitchellcenter_pubs

Part of the Environmental Law Commons, and the Environmental Policy Commons

\section{Repository Citation}

Owen, Dave, "Critical Habitat and the Challenge of Regulating Small Harms." (2012). Publications. 81.

https://digitalcommons.library.umaine.edu/mitchellcenter_pubs/81

This Article is brought to you for free and open access by DigitalCommons@UMaine. It has been accepted for inclusion in Publications by an authorized administrator of DigitalCommons@UMaine. For more information, please contact um.library.technical.services@maine.edu. 


\title{
CRitical Habitat AND the Challenge of Regulating SMall HaRms
}

\author{
Dave Owen*
}

This Article investigates how the United States Fish and Wildlife Service, the National Marine Fisheries Service, and the courts are implementing the Endangered Species Act's prohibition on "adverse modification" of "critical habitat." That prohibition appears to be one of environmental law's most ambitious mandates, but its actual meaning and effect are contested. Using a database of over 4,000 "biological opinions," interviews with agency staff, and a review of judicial decisions considering the adverse modification prohibition, the Article assesses the extent to which the Fish and Wildlife Service, the National Marine Fisheries Service, and the courts are relying on the adverse modification prohibition to provide habitat protection. It also assesses the extent to which they are providing habitat protection by invoking other ESA provisions. The Article concludes that agency practice and some judicial decisions substantially depart from statutory requirements, with problematic results, but that the agencies still are providing substantial habitat protection through other means. It then considers the implications of these findings, first for ongoing debates about ESA implementation and reform and then for broader discussions about legal strategies for responding to small environmental harms and the incremental degradation they cause.

\section{INTRODUCTION}

On December 7, 2010, the United States Fish and Wildife Service (FWS) reluctantly ${ }^{1}$ designated 187,157 square miles of "critical habitat" for the polar bear, ${ }^{2}$ a species protected under the Endangered Species Act $(\mathrm{ESA}){ }^{3}$ According to the agency, this was a fairly inconsequential act. FWS predicted minimal regulatory changes, ${ }^{4}$ only the slightest of economic impacts, ${ }^{5}$ and no conservation benefit to the species. ${ }^{6}$ But those predictions are difficult to

* Associate Professor, University of Maine School of Law. I thank Rachel Bouvier for statistical help; Dmitry Bam, Eric Biber, David Cluchey, Holly Doremus, Sarah Schindler, and Jenny Wriggins for comments on earlier drafts; participants in the New England Junior Faculty Scholarship Workshop at Suffolk University for comments on the project concept; many Fish and Wildlife Service and National Marine Fisheries Service staff members for conducting interviews and responding to my extensive FOIA requests; and Shannon Carroll for exceptional research assistance.

${ }^{1}$ Litigation had forced the agency's hand. See U.S. Fish and Wildlife Service Proposes Polar Bear Critical Habitat, October 22, 2009, at http://alaska.fws.gov/fisheries/mmm/polarbear/pdf/PB\%20CritHab\%20Prop.NR.FINAL.pdf.

${ }^{2}$ Endangered and Threatened Wildlife and Plants; Designation of Critical Habitat for the Polar Bear (Ursus maritimus) in the United States, 75 Fed. Reg. 76086,76086 (Dec. 7, 2010)

3 16 U.S.C. $\S \S 1531-44$ (2006).

${ }^{4}$ INDUSTRIAL ECONOMICS, INC. AND NORTHERN ECONOMICS, ECONOMIC ANALYSIS OF DESIGNATION OF Critical Habitat For the Polar BeAR In THE United States ES-6 (2010) ("Critical habitat is therefore not expected to result in additional regulation").

${ }^{5}$ Id. ("economic impacts are forecast to be limited to additional administrative costs"). 
reconcile with the text of the ESA. The statute's protections for critical habitat appear extensive and stringent; they are, according to one prominent legal scholar, "the highest promontory of the boldest section of the strongest environmental law in the world." The potential objects of regulation are almost infinitely numerous, for the habitat of the polar bear is threatened by greenhouse gas emissions throughout the nation. ${ }^{8}$ Some environmental advocates therefore hope, and some industries fear, that the designation has created a legal lever to halt some of the actions that are incrementally consigning the polar bear to extinction. ${ }^{9}$

The plight of the polar bear is compelling in its own right—-the species has become the poster animal for climate change activism — and it also exemplifies a classic legal challenge. Many of environmental law's greatest remaining problems are caused by the cumulative effects of many actions, each of which contributes only a small increment to the larger problem. ${ }^{10}$ If the causal links between those individual actions and the larger problem are indirect, uncertain, or obscure, the problems become even harder to address. ${ }^{11}$ Climate change is a classic example; although the ultimate environmental challenge is enormous, no single actor is the primary cause, and millions of actions incrementally contribute. But it is not the only one. The United States'

${ }^{6} I d$. at ES-7 ("the Service does not anticipate that the designation of critical habitat will result in additional conservation requirements for the polar bear").

${ }^{7}$ William H. Rodgers Jr., Indian Tribes, in THE ENDANGERED SPECIES ACT AT THIRTY: RENEWING THE Conservation Promise 170, 170 (Dale D. Goble et al. eds. 2006).

${ }^{8}$ See Determination of Threatened Status for the Polar Bear (Ursus maritimus) Throughout Its Range, 73 Fed. Reg. 28212, 28292-93 (May 15, 2008). The bear also is threatened by emissions from the rest of the world, but the ESA's extraterritorial effect is limited.

${ }^{9}$ See, e.g., Carl Portman, Resource Dev. Council, Comments of the Resource Development Council Proposed Rule to Designate Critical Habitat for the Polar Bear (FWS-R7-ES-2009-0042) 3 (2010), available at http://www.regulations.gov/\#!documentDetail;D=FWS-R7-ES-2009-0042-0230.2 (warning of a "vast disconnect between the Service's findings and assurances ... and the intentions of [the Center for Biological Diversity] and other environmental groups"). FWS has taken pains to deny the possibility of such regulation. See INDUSTRIAL ECONOMICS, INC. AND NORTHERN ECONOMICS, supra note 4, at ES-6 ("Critical habitat designation for the polar bear will not be used by the Service as a vehicle to regulate climate change.”).

${ }^{10}$ See, e.g., J.B. Ruhl and James Salzman, Climate Change, Dead Zones, and Massive Problems in the Administrative State: A Guide for Whittling Away, 98 CAL. L. REV. 59, 64-65 (2010); William Odum, Environmental Degradation and the Tyranny of Small Decisions, 32 BIOSCIENCE 728, 728 (1982).

${ }^{11}$ See Daniel C. Esty, Toward Optimal Environmental Governance, 74 N.Y.U. L. REV. 1495, 1545-46 (1999). 
greatest remaining water quality challenges arise from the cumulative effect of many sources of stormwater runoff. ${ }^{12}$ Some of the most persistent air pollution problems derive largely from the collective emissions of millions of engines. ${ }^{13}$ Indeed, similar challenges pervade regulatory governance, as the recent economic crisis - a crisis brought on by the cumulative effect of thousands of ill-advised mortgages and risky investment decisions - made abundantly clear. Finding legal solutions for these problems is not easy, ${ }^{14}$ but it is essential.

This Article advances that search by considering regulatory protection of critical habitat. That protection flows primarily from section 7 of the ESA, which prohibits federal agencies from taking, permitting, or funding any action "likely to ... result in the destruction or adverse modification" of critical habitat. ${ }^{15}$ In theory, this "adverse modification" prohibition, as it is conventionally known, should address the sort of incremental environmental degradation that threatens many species, including the polar bear. ${ }^{16}$ Indeed, it appears to be one of the farthestreaching mandates in all of environmental law. ${ }^{17}$ Practice, however, may be very different. To explore how the services actually protect critical habitat, I reviewed the results of approximately three thousand recent "biological opinions" prepared by the FWS or the National Marine Fisheries Service (NMFS; collectively, I refer to both agencies as "the services"). ${ }^{18}$ These biological opinions analyze whether a federal action will impermissibly affect critical habitat or "jeopardize" the survival of listed species. ${ }^{19}$ In practice, biological opinions have, as the

\footnotetext{
${ }^{12}$ See Jonathan Cannon, A Bargain for Clean Water, 17 N.Y.U. ENVTL. L.J. 608, 610-11 (2008).

${ }^{13}$ See, e.g., Carol Rose, Environmental Law Grows up (More or Less), and what Science Can Do to Help, 9 LEWIS \& CLARK L. REV. 273, 279-80, 283-84 (2005) (providing examples from water and air pollution control); Ruhl and Salzman, supra note 10, at 74-75 (describing causes of urban sprawl).

${ }^{14}$ See Stephen R. Dovers, Sustainability: Demands on Policy, 16 Journal of Public Policy 303, 312 (1996) (asserting that the difficulty "stems in large part from the inherent inability of the mainstay of most environmental policy, project oriented assessment, to handle impacts accruing from a number of separate projects").

${ }_{16}^{15} 16$ U.S.C. $§ 1536(a)(2)(2006)$.

${ }^{16}$ See infra Part II.

${ }^{17}$ See Rogers, supra note 7, at 170.

${ }^{18}$ For discussion of the process through which the services generate these opinions, see infra Part II.A.2.

${ }^{19}$ See 16 U.S.C. $\S 1536$ (b) (2006).
} 
Supreme Court has put it, a "virtually determinative" effect upon whether and how federal actions proceed. ${ }^{20}$ I also reviewed all judicial decisions considering regulatory protections for critical habitat. $^{21}$ Finally, I interviewed agency staff to explore their experiences with critical habitat protection. The result is the first systematic empirical review of the ways critical habitat actually receives regulatory protection. ${ }^{22}$

This inquiry begins filling a substantial gap in the otherwise extensive literature on the ESA. Though critical habitat has been highly controversial ${ }^{23}$ — "an agony of the ESA," in Professor Oliver Houck's words ${ }^{24}$ — the controversy has swirled primarily around critical habitat designations. Few studies have attempted to explain how the services actually protect critical habitat once it is designated, or to what effect, and none has provided the breadth or depth of this inquiry. Perceptions vary widely. Some legal commentators have suggested that the critical habitat provisions create remarkably powerful protective mechanisms. ${ }^{25}$ Some economic studies have found, or simply assumed, dramatic impacts upon regulated entities. ${ }^{26}$ But the services have often claimed that the critical habitat provisions are completely redundant, and that other

\footnotetext{
${ }^{20}$ Bennett v. Spear, 520 U.S. 154, 170 (1997).

${ }^{21}$ A larger body of caselaw considers decisions to designate critical habitat, but my focus is on what happens after a designation is finalized.

${ }^{22}$ While broad, the review is not comprehensive. See infra Part III (describing regulatory effects not addressed by this study).

${ }^{23}$ See John Copeland Nagle, The Effectiveness of Biodiversity Law, 24 J. OF LAND USE AND ENVTL. L. 203, 205 (2009) (describing critical habitat as “especially controversial”); Scott Norris, Only 30: A Portrait of the Endangered Species Act as a Young Law, 54 BIOSCIENCE 288, 291 (2004) ("If the Endangered Species Act ... has become a battleground, the front line is the issue of critical habitat.").

${ }^{24}$ Oliver A. Houck, The Endangered Species Act and Its Implementation by the U.S. Departments of Interior and Commerce, 64 U. COLO. L. REV 277, 297 (1993).

${ }^{25}$ See, e.g., James Salzman, Evolution and Application of Critical Habitat under the Endangered Species Act, 14 HARV. ENVTL. L. REV. 311, 311 (1990) ("the ESA's most controversial and influential enforcement tool”); Rodgers, supra note 7.

${ }^{26}$ Jeffrey E. Zabel and Robert W. Patterson, The Effects of Critical Habitat Designation on Housing Supply: An Analysis of California Housing Construction Activity, 46 J. OF REGIONAL SCI. 67, 90 (2005) (finding substantial effects even outside the designated critical habitat area); John M. Quigley and Aaron M. Swoboda, The urban impacts of the Endangered Species Act: A general equilibrium analysis, 61 J. OF URBAN ECON. 299,304 (2007) ("For simplicity, we assume that lands designated as critical habitat cannot be used to produce housing at all.").
} 
statutory provisions obviate the need for the "adverse modification" prohibition to exist. ${ }^{27}$ A few studies have used regression analyses to test whether critical habitat designations lead to improvements in species status, but the results are conflicting, and the studies do not purport to explain why critical habitat protection is (or is not) producing results. ${ }^{28}$ Other researchers have used case studies to explore ways in which critical habitat can provide protection, but, as with any case study, the potential for drawing generalized conclusions is limited. ${ }^{29}$ The process of implementing the adverse modification prohibition therefore remains a black box with disputed outputs, and a primary purpose of this inquiry is to expose that black box's inner workings. ${ }^{30}$

The results reveal a large discrepancy between statutory requirements and actual practice. Notwithstanding statutory language that seems to mandate a major role for the adverse modification prohibition, the services have given it hardly any independent significance, instead treating the prohibition as a redundant add-on to the ESA's other protective measures. ${ }^{31}$ The services also have consistently treated small-scale habitat degradation as exempt from the adverse modification prohibition, even though no such exemption appears in the ESA itself. $^{32}$ That approach has persisted even after a series of court cases called it into question. The services

\footnotetext{
${ }^{27}$ Department of the Interior, Fish and Wildlife Service, Notice of Intent to Clarify the Role of Habitat in Endangered Species Conservation, 64 Fed. Reg. 31871 , 31872 (1999) ("For almost all species, the adverse modification and jeopardy standards are the same., resulting in critical habitat being an expensive regulatory process that duplicates the protection already provided by the jeopardy standard."). For discussion of those other provisions, see infra Part II.

${ }^{28}$ See Martin F. J. Taylor et al., The Effectiveness of the Endangered Species Act: A Quantitative Analysis, 55 BIOSCIENCE 360, 361-63 (2005) (“Critical habitat promotes species survival and recovery."); Jeffrey J. Rachlinski, Noah by the Numbers: An Empirical Evaluation of the Endangered Species Act, 82 CORNELL L. REV. 356, 384 (1997) ("Designation of critical habitat appeared to benefit species, but the evidence for this proposition was weak."); but see Joe Kerkvliet and Christian Langpap, Learning from endangered and threatened species recovery programs: A case study using the U.S. Endangered Species Act recovery scores, 63 ECOLOGICAL ECON. 499, 506-07 (2007) (finding no causal relationship).

${ }^{29}$ See Kieran F. Suckling and Martin Taylor, Critical Habitat and Recovery, in THE ENDANGERED SPECIES ACt At 30: Renewing the Conservation Promise 80-85 (Dale D. Goble et al. eds 2006).

${ }^{30}$ This problem is not limited to the ESA's critical habitat provisions. See Barton H. Thompson, The Endangered Species Act: A Case Study in Takings and Incentives, 40 STAN. L. REV. 305, 307 (1997) ("One problem with undertaking a case study of the ESA is that there is a scarcity of verifiable data and information.").

${ }^{31}$ See infra Part IV.

${ }^{32}$ See id.
} 
also have struggled to articulate a standard for determining what constitutes adverse modification, and, in many individual biological opinions, have offered rationales that seem to ignore both statutory text and the incremental nature of the habitat degradation most species face. ${ }^{33}$ While critical habitat has assumed slightly more significance in the courts, the judiciary also has not decided how protective the critical habitat provisions should be. ${ }^{34}$ The provisions have had some impact, notwithstanding the services' periodic assertions that critical habitat designations are purely a waste of money and time. But the effects on regulatory processes, though real, have been minor and subtle.

These disparities between statutory text and actual practice are only half of the story, however. Even if the adverse modification prohibition is doing little to protect critical habitat, the services are invoking other provisions of the ESA as substitutes. ${ }^{35}$ Those efforts are extensive and, in some ways, pragmatic and creative. ${ }^{36}$ There are problems with these alternative approaches-most importantly, they seem designed to slow rather than stop habitat degradation — but they nevertheless provide substantial habitat protection, albeit not in the ways the statute itself might lead one to expect. ${ }^{37}$

These paradoxical results undermine some of the classic narratives of ESA implementation and, more generally, are inconsistent with some prevalent understandings of administrative agency behavior. One of the dominant narratives, raised often though not exclusively by opponents of the act, suggests the ESA creates an inflexible "command-andcontrol" regulatory scheme. ${ }^{38}$ That view reflects a broader criticism alleging that environmental law is generally characterized by rigid, top-down schemes myopically implemented by tunnel-

\footnotetext{
${ }^{33}$ See infra Part IV.A.

${ }^{34}$ See infra Part IV.C.

${ }^{35}$ See infra Part IV.B.

${ }^{36}$ See id.

${ }^{37}$ See id.

${ }^{38}$ See infra Part V.A.
} 
visioned agencies. ${ }^{39}$ A rather different critique, often asserted by frustrated supporters of the act's basic goals, asserts that the ESA is a "paper tiger, ${ }^{, 40}$ which reluctant agencies implement only to the extent compelled by the citizen suits of non-governmental litigants. ${ }^{41}$ Though these critiques may seem nearly opposite, both share an underlying cynicism about governmental implementation of the ESA - a cynicism that also typifies much of the rhetoric of regulatory governance. $^{42}$ In both narratives, the services are somewhat passive entities, either implementing an unreasonable statute with mindless rigidity or persistently bowing to the focused pressure of moneyed interest groups, ${ }^{43}$ and ESA implementation is fundamentally flawed. Not surprisingly, both narratives also support calls for dramatic reforms.

But neither narrative explains what the services are actually doing. The assertions of inflexibility are belied by the services' selective non-use of a seemingly mandatory statutory provision. They also cannot explain the services' substitute approaches, for despite the conventional characterizations of ESA-based regulation as a centralized, rigid, command-andcontrol scheme, those alternative approaches have evolved largely through decentralized, negotiation-driven processes. ${ }^{44}$ The paper tiger narrative comes closer to the mark, for the

${ }^{39}$ See, e.g., Richard B. Stewart, Environmental Quality as a National Good in a Federal State, 1997 U. CHI. LEGAL F. 199, 203, 213 (describing a "burdensome" system with "many grievous flaws").

40 See J.B. Ruhl, Is the Endangered Species Act Eco-Pragmatic?, 87 MINN. L. REV. 885, 886 (2003) (explaining (and rejecting) this view of the ESA).

${ }^{41}$ See, e.g., Houck, supra note 24, at 311 ("the ESA's prohibitions against jeopardy and habitat designation are enforced solely through citizen actions in the courts").

${ }^{42}$ Even President Obama, though generally sympathetic to regulatory initiatives, has prominently belittled this scheme. See Barack Obama, Remarks by the President at the State of the Union Address, January 25, 2011, at http://www.whitehouse.gov/the-press-office/2011/01/25/remarks-president-state-union-address (suggesting that a bifurcated system of authority over salmon exemplifies a flawed "government of the past").

${ }^{43}$ This view parallels conceptions of administrative agency action prevalent both in some law-andeconomics critiques of regulatory governance, in public choice theory, and, though from a different ideological perspective, in environmentalists' arguments in favor of citizen intervention in administrative decisionmaking. See, e.g., Nathaniel O. Keohane et al., The Choice of Instruments in Regulatory Policy, 22 HARV. ENVTL. L. REV. 313 , 320-21 (1998) (summarizing law and economics studies asserting that regulatory policy passively reflects external interests); DANIEL A. FARBER \& PHILIP P. FrICKEY, LAW AND PUBliC CHOICE: A CRITICAL INTRODUCTION 17-21 (1991) (describing public choice theory, which asserts a similar view and informs many of the law and economics studies); Joseph L. SAX, DEFENDING THE ENVIRONMENT 63-64 (1970).

${ }^{44}$ See infra Part V.A. 
services' chosen regulatory approaches depart from statutory text in ways that appear to compromise species protection. But the services still are providing a lot of habitat protection, often in the face of intense resistance, and even where external pressure from environmental groups can provide at most a partial explanation for their actions. ${ }^{45}$ The incompleteness of both of these narratives has implications for ESA reform efforts and for environmental law reform more generally. Most importantly, while reforms are needed, they need not be drastic. Existing law and existing institutions contain positive features worth building upon.

The Article therefore closes by recommending several modest reforms, and in so doing returns to one of the core dilemmas of regulating incremental environmental degradation. Any such regulatory effort must resolve when, if ever, harms are too small to address, and how to compensate for the harms that escape regulatory coverage. ${ }^{46}$ The services have never figured out a coherent answer to those questions. Workable answers do exist; a combination of regulatory approaches developed in several other areas of environmental law could improve the critical habitat program. ${ }^{47}$ None of these approaches is a panacea, each has its critics and its flaws, and my recommendations in combination may seem to prescribe a sort of regulatory kitchen-sink soup. But the jumble is partly the point. The sometimes-bewildering complexity of environmental law can make simplification seem like an essential goal, and one might readily presume that some single regulatory instrument-perhaps an existing tool, perhaps something new-should predominate. ${ }^{48}$ The critical habitat experience illustrates, however, that regulators

\footnotetext{
${ }^{45}$ See infra Part V.B.

${ }^{46}$ This question was famously addressed by the Supreme Court's decision in Massachusetts v. EPA, which noted that agencies should "whittle away" at massive problems. 549 U.S. 497, 524 (2007). But that observation begs the question, answered by neither the majority nor the dissent, how one determines when the cut is too small to be worth the whittler's effort.

${ }^{47}$ See infra Part VI.

${ }^{48}$ See, e.g., Mary Christina Wood, Advancing the Sovereign Trust of Government to Safeguard the Environment for Present and Future Generations (Part I): Ecological Realism and the Need for a Paradigm Shift,
} 
often need a variety of tools, and, subject to some statutory guidance, can and will use that variety in creative and effective ways. Environmental law's cacophony of regulatory approaches and options therefore holds value, and the best approach for addressing major environmental challenges will be not some dazzling new innovation but rather a complex, label-defying combination of existing approaches.

This Article's analysis proceeds as follows. Part II explains how the ESA protects critical habitat and how those provisions fit within the larger statutory scheme. Part III explains the methodology I used to assess how the services implement those provisions in practice. Part IV sets forth the results, exploring both the discrepancy between statutory mandates and actual practice and the alternative ways the services are providing habitat protection. Part $\mathrm{V}$ considers the implications of those results for traditional views of the ESA, and concludes that the results undermine two of the predominant narratives of ESA implementation. Part VI explains how the services' regulatory approaches could be improved. It also reflects more broadly on this study's lessons for regulatory efforts to address the challenges of incremental environmental degradation.

\section{The StATUtory ReQUiREMENTS}

The ESA is the United States' most important law for the protection of biodiversity. The act is designed to prevent the extinction of imperiled animal and plant species and to promote those species' recovery. ${ }^{49}$ To those ends, it requires the services to "list" species that are in

\footnotetext{
39 ENVTL. L. 43, 57 (2009) (citing "a regulatory complexity that is mind-boggling" as a primary reason for environmental law's alleged failure).

${ }^{49}$ See 16 U.S.C. § 1531(b) (defining "conservation" of species as the core statutory goal); id. § 1532(3) (defining conservation in terms of recovery).
} 
danger of extinction ${ }^{50}$ and to designate critical habitat for those species. ${ }^{51}$ It then provides listed species and their habitat with a series of regulatory protections.

The ESA's focus on habitat is no coincidence. For decades, scientists have been warning that habitat loss is the single most important threat to biodiversity, ${ }^{52}$ and Congress was well aware of this threat when it enacted the statute. ${ }^{53}$ The challenge has only grown in recent years, with climate change now adding to a host of pre-existing stressors. ${ }^{54}$ Some predictions of the combined impacts of these stressors are staggering. A 2004 study published in Science, for example, predicted that with the added stress caused by climate change, $15 \%$ to $37 \%$ of all global species could be committed to extinction by $2050 .^{55}$

This section explains the ESA's habitat-protection provisions, beginning with critical habitat, then discussing other key provisions that are partially, though not exclusively, focused on habitat protection, and then explaining how-on paper, at least - the different provisions would seem to interact.

\section{A. The Critical Habitat Requirements}

\section{Definitions and designation procedures}

Critical habitat is a crucial portion of the historic habitat of a threatened or endangered species. ESA section 3 defines the term "critical habitat" as including both occupied and unoccupied habitat with "physical or biological features... essential to the conservation of the

\footnotetext{
${ }^{50}$ See id. $\$ 1533$.

${ }^{51} I d . \S 1533(\mathrm{a})(3)$.

${ }^{52}$ See, e.g., David .S. Wilcove et al., Quantifying threats to imperiled species in the United States, 48 BiosciEnCE 607, 609 (1998).

${ }^{53}$ See Amy Sinden, The Economics of Endangered Species: Why Less is More in the Economic Analysis of Critical Habitat Designations, 28 HARV. ENVTL. L. REV. 129, 143 \& n.65 (2004).

${ }^{54}$ See Intergovernmental Panel on Climate Change, Climate Change 2007: Working Group II: IMPACTS, AdAPTION AND VulnerABILITy, SumMARY FOR POLICYMAKERS 11 (2007); J.B. Ruhl, Climate Change and the Endangered Species Act: Building Bridges to the No-Analog Future, 88 B.U. L. REV. 1 (2008).

${ }^{55}$ Chris D. Thomas et al., Extinction Risk from Climate Change, 427 NATURE 145, 145 (2004); see IPCC, supra note 54, at 11 ("Approximately 20-30\% of plant and animal species assessed so far are likely to be at increased risk of extinction if increases in global average temperature exceed $1.5-2.5^{\circ} \mathrm{C}$.”).
} 
species." $" 56$ The statute sets some limits on the breadth of the designation, and critical habitat cannot include the entire historic range of the species. ${ }^{57}$ The services also may invoke economic costs to exclude some areas from the designation. ${ }^{58}$ But if habitat is necessary for the species' survival or recovery, it should be included.

In almost all circumstances, that habitat should be designated whenever the services determine that a species is threatened or endangered. Under ESA section 4, the services, "to the maximum extent prudent and determinable, shall... designate" critical habitat, and "may, from time-to-time thereafter as appropriate, revise such designation."59 For years, the services observed that mandate largely in the breach. ${ }^{60}$ But judicial decisions have consistently compelled designations, and the services are slowly catching up. ${ }^{61}$ Over 600 species now have designated critical habitat, and the percentage of species with designated habitat is gradually rising. ${ }^{62}$

In practice, the designations generally describe particular geographic areas, though they may also describe certain landscape features that lead to inclusion in or exclusion from the

${ }^{56} 16$ U.S.C. $\S 1532(5)$ (2006). The ESA defines “conservation” in terms of recovery, and critical habitat therefore is habitat with features that make it essential to species' survival or recovery.

${ }^{57} I d . \S 1532(5)(\mathrm{C})$.

${ }_{58}^{58} I d . \S 1533(\mathrm{~b})(2)$.

${ }^{59} I d$. $\S 1533(\mathrm{a})(3)$. In an approach that departs from much of the rest of the ESA, the services must consider economic impact when designating critical habitat. Id. §1533(b)(2).

${ }^{60}$ See Sinden, supra note 53, at 157-59.

${ }^{61}$ See Gifford Pinchot Task Force v. U.S. Fish and Wildlife Service, 378 F.3d 1059, 1069-71 (9th Cir. 2004); N.M. Cattle Growers Ass'n v. U.S. Fish and Wildlife Serv., 248 F.3d 1277, 1283 \& n. 2 (10th Cir.2001); Sierra Club v. U.S. Fish and Wildlife Serv., 245 F.3d 434, 441-42 (5th Cir. 2001).

${ }^{62}$ For a list of species with designated critical habitat, see U.S. Fish and Wildlife Service, Listed Species with Critical Habitat, at http://ecos.fws.gov/tess_public/CriticalHabitat.do?nmfs=1 (last checked December 15, 2010). A full list of protected species is available at http://www.fws.gov/endangered/species/us-species.html (last checked December 15, 2010). As of February 26, 2011, 603 of the 1,371 listed U.S. species have designated critical habitat. 
designated area. ${ }^{63}$ Millions of acres of habitat have now been designated, and in some parts of the country, swaths of critical habitat cover much of the map. ${ }^{64}$

\section{Procedural and substantive protections}

The actual protection of those millions of acres of critical habitat derives from ESA section $7 .^{65}$ Substantively, section 7 limits the ability of federal agencies to undertake, fund, or permit actions that degrade critical habitat. It directs those agencies to "insure that any action authorized, funded, or carried out by such agency... is not likely to... result in the destruction or adverse modification of habitat of such species which is determined by the Secretary, after consultation as appropriate with affected States, to be critical." ${ }^{, 66}$ In practice, this provision is often simply referred to as the "adverse modification prohibition."

Procedurally, section 7 requires federal agencies taking actions ("action agencies," in ESA-speak) that might adversely affect listed species to "consult" with the relevant service ${ }^{67}$ and obtain a written report known as a "biological opinion." The biological opinion expresses the service's opinion about whether the project will "jeopardize" the survival of listed species (a concept explained in more detail below) or will result in adverse modification. ${ }^{68}$ If the service concludes that adverse modification is likely to result from the project, its biological opinion should identify "reasonable and prudent alternatives" that could be implemented without causing adverse modification or jeopardy. ${ }^{69}$ Once the action agency has received a biological opinion, it

\footnotetext{
${ }^{63}$ See, e.g., Designation of Critical Habitat for the Polar Bear (Ursus maritimus) in the United States, 75 Fed. Reg. 76086 , 76119 (Dec. 7, 2010) (excluding "manmade structures on all types of land ownership").

${ }^{64}$ See U.S. Fish and Wildlife Service, Critical Habitat Portal, at http://crithab.fws.gov/. The link accesses an on-line mapping tool. Total figures are hard to find, but the critical habitat for polar bears alone encompasses 187,157 square miles. U.S. Fish \& Wildlife Service, Polar Bear Critical Habitat: Some Frequently Asked Questions (2010) at http://alaska.fws.gov/fisheries/mmm/polarbear/pdf/critical_habitat_factsheet_11_2010.pdf.

${ }^{65} 16$ U.S.C. $\S 1536$ (2006).

${ }^{66} I d . \S 1536(\mathrm{a})(2)$.

${ }^{67}$ With some exceptions, NMFS holds jurisdiction over marine and anadromous fish species and FWS holds jurisdiction over terrestrial and freshwater species.

${ }^{6} 16$ U.S.C. $\S 1536$ (2006).

${ }^{69} I d . \S 1536(\mathrm{~b})(4)$.
} 


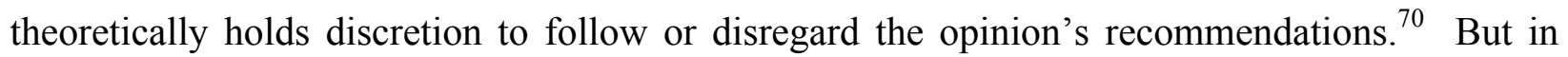
practice, action agencies hardly ever proceed with an action that the services predict will cause adverse modification or jeopardy. ${ }^{71}$

This "formal consultation" process is usually preceded by and often intertwined with a more informal process in which the action agency and the services negotiate changes to the project. $^{72}$ Those discussions can result in a variety of outcomes. First, the services often concur that a project will not adversely affect listed species or their critical habitat, in which case the

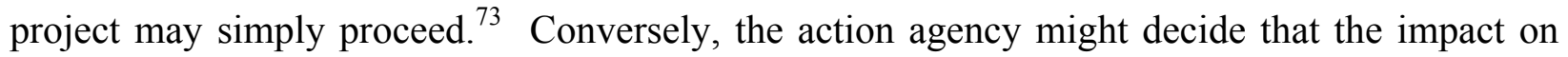
species will be too large and unavoidable and might walk away from the project. It might also significantly modify the project, and those changes can result in a new project description or in the inclusion in the biological opinion of "conservation measures," which are binding conditions that the action agency must implement for the opinion to remain valid. ${ }^{74}$ The services might also determine that a project will not lead to jeopardy or adverse modification but nevertheless may find that it will "take" listed species. ${ }^{75}$ The services then will usually impose conditionsknown in ESA parlance as "reasonable and prudent measures"-designed to reduce the level of take. $^{76}$ Finally, the biological opinion may also include "conservation recommendations," which are non-binding measures that would minimize harm to species or promote their recovery. ${ }^{77}$ The jumble of terms and acronyms is bewildering, but in summary, there are many ways that consultation can change a project and minimize its negative impacts on habitat.

\footnotetext{
${ }^{70} 50$ C.F.R. $\S 402.15$ (a).

${ }^{71}$ See Bennett v. Spear, 520 U.S. 154, 170 (1997).

72 U.S. Fish \& Wildlife SERVICE AND NATIONAL MARINE Fisheries SERVICE, ENDANGERED SPECIES CONSUlTATION HANDBOOK 3-1 (1998).

${ }^{73}$ Id. at $3-1$.

${ }^{74}$ See id. at xii.

${ }^{75} \mathrm{Id}$. at 4-45 to 4-52. For discussion of the ESA's "take" prohibition, see infra part II.C.

${ }^{76}$ See 16 U.S.C. $\S 1536($ b)(4) (2006); CONSULTATION HANDBOOK, supra note 72, at 4-52 to 4-54.

77 See CONSULTATION HANDBOOK, supra note 72, at xii.
} 
Every year, thousands of actions are subject to this consultation process. Section 7 applies only to federal agencies, and therefore purely state, local, or private actions do not require consultation. ${ }^{78}$ But many of the governmental and private actions that affect species habitat involve federal funding or permits, ${ }^{79}$ and the federal government itself also carries out hundreds of species-affecting projects every year. ${ }^{80}$

B. The Jeopardy Prohibition

In addition to its adverse modification prohibition, section 7 also precludes federal agencies from taking actions "likely to jeopardize the continued existence" of any listed species. ${ }^{81}$ This prohibition is implemented through the same consultation process, and biological opinions always state whether or not the project is likely to cause jeopardy. ${ }^{82}$ The jeopardy analysis should encompass any threat a project poses to listed species, including but not limited to habitat degradation, and in practice most jeopardy analyses include extensive discussion of the action's potential habitat effects. ${ }^{83}$

The jeopardy prohibition has received much more attention than the prohibition on adverse modification. Some academic analyses of ESA section 7 focus entirely on jeopardy; ${ }^{84}$ practicing attorneys often just refer to section 7 as "the jeopardy prohibition," as though the adverse modification prohibition did not exist; and, as discussed in more detail below, the

\footnotetext{
${ }^{78} 16$ U.S.C. $\S 1536(\mathrm{a})(2)$ (2006) (imposing obligations on "[e]ach federal agency").

${ }^{79}$ For example, many development projects require dredge and fill permits issued by the U.S. Army Corps of Engineers, and many transportation projects depend on federal funding.

${ }^{80}$ See infra Part IV (discussing the large number of consultations for fish species alone).

${ }^{81} 16$ U.S.C. $\S 1536(\mathrm{a})(2)$.

${ }^{82}$ CONSUltation HANDBOOK, supra note 72 , at 4-33 to 4-34.

${ }^{83}$ With the exception of biological opinions for ocean fishing activities, the jeopardy analysis in every biological opinion I reviewed included discussion, usually extensive, of habitat impacts.

${ }^{84}$ See, e.g., Ruhl, supra note 54, at 42-49 (focusing on jeopardy while analyzing section 7's role in responding to climate change).
} 
services have often asserted that the jeopardy prohibition obviates the need for regulatory protection of critical habitat. $^{85}$

\section{The Take Prohibition}

The ESA's other major substantive prohibition comes from section 9, which makes it unlawful for "any person" to "take" any endangered species. ${ }^{86}$ The act defines "take" broadly. In addition to actions like hunting animals, the definition includes actions that "harm" listed species, ${ }^{87}$ and the Supreme Court has upheld agency regulations that treat some forms of habitat modification as prohibited "takes." 88 Consequently, as with the jeopardy prohibition, a key part of the take prohibition's role is to protect habitat.

Though far-reaching, the take prohibition is not absolute. Private parties may obtain "incidental take permits" if they prepare "habitat conservation plans" that meet the requirements of ESA section $10 .{ }^{89}$ Those habitat conservation plans generally include measures to minimize and compensate for the expected take. ${ }^{90}$ Federal agencies (and recipients of permits or funding from federal agencies) also may obtain "incidental take authorization" if they complete the section 7 consultation process and implement the "reasonable and prudent measures" specified in a biological opinion. ${ }^{91}$ But even with those potential exceptions, the take prohibition is generally viewed as a key part of the substantive core of the ESA. ${ }^{92}$

\section{The Combination of Approaches}

${ }^{85}$ See infra notes 108-112 and accompanying text. See also Barton H. Thompson, People or Prairie Chickens: The Uncertain Search for Optimal Biodiversity, 51 STAN. L. REV. 1127, 1141 ("critical habitat plays only a secondary role").

${ }^{86} 16$ U.S.C. $\S 1538(a)(1)$ (2006). By regulation, the services have extended these protections to many threatened species.

${ }^{87}$ Id. $\S 1532(19)$.

${ }^{88}$ Babbitt v. Sweet Home Chapter of Communities for a Great Oregon, 515 U.S. 687 (1995).

${ }^{89} 16$ U.S.C. § 1539(a); see J.B. Ruhl, How to Kill Endangered Species, Legally: The Nuts and Bolts of Endangered Species Act “HCP” Permits for Real Estate Development, 5 ENVTL. LAW. 345 (1999).

${ }^{90}$ See 16 U.S.C. § 1539(a)(2)(A)(ii) (2006).

${ }^{91} \mathrm{Id}$. $\S 1536(\mathrm{~b})(4)$.

${ }^{92}$ See Zygmunt J.B. Plater et al., Environmental Law and Policy: Nature, Law, ANd Society 428 (4th ed. 2010). 
Within this suite of protections, the adverse modification prohibition occupies an interesting - and hotly debated - niche. Without question, its protections are partly redundant, for some habitat modification will be precluded by the jeopardy prohibition, the take prohibition, or both. For many years, the official position of the services was that the adverse modification protections were completely redundant, a position with which some commentators concurred. ${ }^{93}$ But the plain language of the statute indicates, and some other commentators and courts have agreed, that the critical habitat provisions are not entirely redundant, and that for many federal agency actions they should hold independent significance. ${ }^{94}$

The potential for overlap is obvious. If a federal agency action is likely to cause major negative impacts to listed species, the jeopardy prohibition should apply, and the critical habitat provisions will just offer an overlapping layer of protection. The controversy at issue in Tennessee Valley Authority v. Hill, the Supreme Court's first seminal ESA case, provides a good example. ${ }^{95}$ There, the TVA proposed to operate a dam expected to obliterate all known habitat, including all designated critical habitat, of the snail darter, a listed species. ${ }^{96}$ Such an action was clearly likely to cause both adverse modification and jeopardy. Similarly, if an action will lead to clear and discernible impacts to identifiable animals, the take prohibition should apply, ${ }^{97}$ and the critical habitat protections again just offer a redundant layer of protection. TVA v. Hill provides an example here as well; the killing of all known members of a species would clearly constitute a prohibited set of takes. Nevertheless, there would appear, at least on paper, to be

${ }^{93}$ See supra note 27 and accompanying text.

${ }_{95}^{94}$ See infra notes 100-105 and accompanying text.

95437 U.S. 153 (1978).

${ }^{96}$ The dam eventually was built, and "[t]o everyone's surprise, the snail darter did not go extinct." Holly Doremus, The Story of TVA v. Hill: A Narrow Escape for a Broad New Law, in ENVIRONMENTAL LAw STORIES 109, 134 (Richard J. Lazarus and Oliver O. Houck eds. 2005).

${ }^{97}$ See supra notes 86-Error! Bookmark not defined. and accompanying text. 
circumstances in which the adverse modification prohibition would apply but the jeopardy and take prohibitions would not. ${ }^{98}$

\section{Adverse modification and jeopardy}

The adverse modification prohibition appears to go beyond the jeopardy prohibition in two categories of actions. ${ }^{99}$

First, some federal actions may adversely modify habitat but not cause enough harm to create a likelihood of jeopardy. The services have consistently asserted that even after a species has been listed, it is generally possible to cause additional harm to the species without pushing it over the brink into jeopardy. ${ }^{100}$ At least in some circumstances, this is a plausible statutory interpretation. $^{101}$ The adverse modification prohibition, by contrast, is more absolute. The statute does not define the phrase, but its meaning should be clear. "Adverse," in common parlance, means against or for the worse, ${ }^{102}$ and modification, according to Black's Law Dictionary, means "a change to something."103 No size modifiers accompany the phrase "adverse modification;" the ESA does not use "major," "significant," or any other analogous phrase, notwithstanding those words' prominent appearances in other contemporaneously-

${ }^{98}$ But see infra Part IV (discussing the services' apparent determination that these circumstances do not actually exist).

${ }^{99}$ For a parallel analysis of the relationship between jeopardy and adverse modification, see Houck, supra note 24 , at $300-01$.

${ }^{100}$ See CONSULTATION HANDBOOK, supra note 72, at 4-36 (explaining that not all adverse effects will rise to the level of causing jeopardy); Daniel J. Rohlf, Jeopardy under the Endangered Species Act: Playing a Game Protected Species Can't Win, 41 WASHBURN L.J. 114, 141-42 (2001) (describing the services' willingness to allocate the "buffer" of tolerable harm ).

${ }^{101}$ If a species' population is stable or improving, it could absorb some harm from individual actions without its continued existence being jeopardized.

${ }^{102}$ See BlACK'S LAW DiCTIONARY ( $8^{\text {th }}$ Ed. 2004) (defining adverse: "1. Against; opposed (to). 2. Having an opposing or contrary interest, concern, or position. 3. Contrary (to) or in opposition (to). 4. Hostile").

${ }^{103} I d$. ("1. A change to something; an alteration ... 2. A qualification or limitation of something..."). 
drafted environmental laws. ${ }^{104}$ The plain language therefore precludes federal agency actions from causing negative changes to critical habitat, even if the change is small. ${ }^{105}$

Second, some federal actions will adversely modify habitat but will have uncertain impacts upon species' survival. Uncertainty pervades implementation of the ESA. ${ }^{106}$ The services do not always know the extent to which a proposed action will affect a species' viability. Often they are also uncertain about species' status and population trend. ${ }^{107}$ Consequently, determining whether an individual project might pose enough risk to create jeopardy can be quite difficult. Yet the services may still know that the action will adversely affect the species' habitat. Determining whether a single clearcut in spotted owl critical habitat will tip spotted owls into a state of jeopardy may be very difficult, for example, but discerning whether the clearcut will have adverse impacts on critical habitat ought to be much easier.

To say that these interpretations are compelled by statutory language is not to say that they have been adopted by the services. In joint regulations promulgated in the $1980 \mathrm{~s}$, the services defined "adverse modification" not as any adverse change to designated critical habitat, but instead as "a direct or indirect alteration that appreciably diminishes the value of critical habitat for both the survival and recovery of a listed species."108 That definition, as numerous commentators and judicial opinions have pointed out, narrows the definition of adverse modification and gives the green light to actions that might limit recovery without appreciably

\footnotetext{
${ }^{104}$ See, e.g., 42 U.S.C. $§ 4332(C)$ (2006) (requiring environmental impact statements for “major” federal actions "significantly" impacting the environment).

${ }^{105}$ See Rodgers, supra note 7, at 170 ("Backing the tractor over a single salmon redd is an actionable deed of "destruction" or "modification" if the necessary paperwork is done.").

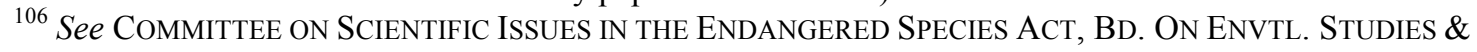
Toxicology, COMM'N On LifE ScIENCES, NAT'L RESEARCH COUNCIL, SCIENCE AND THE ENDANGERED SPECIES ACT 143-54 (1995); Holly Doremus, The Purposes, Effects, and Future of the Endangered Species Act's "Best Available Science" Mandate, 34 EnVTL. L. 397, 438 (2004) ("Uncertainty is endemic in the ESA context."). 531-33 (2007).

${ }^{107}$ See Teresa Woods and Steve Morey, Uncertainty and the Endangered Species Act, 83 InD. L.J. 529,

108 50 C.F.R. $\S 402.02$.
} 
reducing the species' odds of survival. ${ }^{109}$ In their joint consultation handbook, the services stretched that regulatory definition a step further. "Modification or destruction of designated critical habitat that does not reach" the "appreciable" threshold, they claimed, should not count as adverse modification, and "is not prohibited by section 7." phrase "appreciably diminish" to mean "considerably reduce." somewhat deliberate vagueness, but the services apparently intended to create an exception for small-scale modification or destruction of habitat - an exception that appears nowhere in the text of the statute itself. On the basis of these definitions, the agencies then asserted, and some commentators agreed, that the critical habitat protections were redundant. ${ }^{112}$

But these definitions no longer hold any legal force. Environmental groups repeatedly challenged the regulatory definition of adverse modification, arguing that it was inconsistent with the statute, and they repeatedly won. ${ }^{113}$ In December 2004, in response to these decisions, FWS directed its staff to ignore the regulations and rely on statutory text alone. ${ }^{114}$ NMFS soon issued a similar memorandum. ${ }^{115}$ The regulations have not been withdrawn or replaced, but the biological opinions of both services now routinely disclaim any reliance on the regulatory

${ }^{109}$ See, e.g., Sinden, supra note 53, at 153-57; Houck, supra note 24, at 297, 300-01.

${ }^{110} I d$ at $4-35$.

${ }^{111} I d$. at 4-36 to 4-37.

${ }^{112}$ See supra note 27.

${ }^{113}$ Gifford Pinchot Task Force v. U.S. Fish and Wildlife Serv., 378 F.3d 1059, 1069-71 (9th Cir. 2004); N.M. Cattle Growers Ass'n v. U.S. Fish and Wildlife Serv., 248 F.3d 1277, 1283 \& n. 2 (10th Cir.2001); Sierra Club v. U.S. Fish and Wildlife Serv., 245 F.3d 434, 441-42 (5th Cir. 2001).

${ }^{114}$ Memorandum from Marshall Jones, Acting Director, to Regional Directors, Regions 1, 2, 3, 4, 5, 6, and 7 Manager, California-Nevada Operations Office, Dec. 9, 2004, available at http://www.fws.gov/midwest/endangered/permits/hcp/pdf/AdverseModGuidance.pdf.

${ }^{115}$ William T. Hogarth, Ph.D., Memorandum to Regional Administrators, Office of Protected Resources, Re: Application of the "Destruction or Adverse Modification" Standard under Section 7(a)(2) of the Endangered Species Act, Nov. 7, 2005. 
definitions. ${ }^{116}$ The services therefore are back, at least in theory, to the statutory text, and that text gives the jeopardy and adverse modification prohibitions independent roles.

\section{Take and adverse modification}

The take prohibition also overlaps significantly, but not completely, with the ESA's prohibition on adverse modification. Many actions that modify habitat also directly take listed species. A timber sale or a dam project, for example, will have significant adverse impacts on habitat and is also likely to directly kill or harm members of species inhabiting the area. But, as the Supreme Court's Sweet Home Chapter of Communities for a Great Oregon v. Babbitt decision points out, not every habitat modification will result in take. ${ }^{117}$ In his opinion for the Court, Justice Stevens stressed that the take prohibition applies only to actions that "actually kill or injure wildlife." 118 Justice O'Connor elaborated on this point, saying that her concurrence was "predicated on [her] understanding that the challenged regulation is limited to significant habitat modification that causes actual, as opposed to hypothetical or speculative, death or injury to identifiable protected animals." ${ }^{119}$ She later cited an example that clearly demonstrates her understanding of the outer boundaries of the take prohibition. In dissent, Justice Scalia had raised the specter of section 9 applying to "a farmer who tills his field and causes erosion that makes silt run into a nearby river which depletes oxygen and thereby injures protected fish.",120 Under any reasonable definition of the term, that farmer would be adversely modifying critical habitat if the river were so designated; his actions would cause a change, and that change would

\footnotetext{
${ }^{116}$ See, e.g. U.S. Fish ANd Wildlife SERVice, NeW MeXico Ecological SERViCES Field OfFice, Biological Opinion: BuckMan WATER Diversion Project 1 (2007) (hereinafter BuckMAN Diversion BIOLOGICAL OPINION) ("This biological opinion does not rely on the regulatory definition of 'destruction or adverse modification' of critical habitat at 50 CFR 402.02. Instead, we have relied upon the statute and the [Gifford Pinchot Task Force decision]....").

117515 U.S. 687 (1995).

${ }^{118} I d$. at 690, 700 n.13 (quoting the services' joint regulations).

${ }^{119} I d$. at 708-09. Justice O'Connor was not the deciding vote in the case, so her concurrence has no precedential authority. But it does suggest how other courts might interpret the boundaries of the take prohibition. ${ }^{120} \mathrm{Id}$. at 719 .
} 
be for the worse. ${ }^{121}$ But according to Justice O'Connor, the farmer would not be causing a take, presumably because the causal chain between his action and harm to identifiable individual fish would be too attenuated or too difficult to discern. ${ }^{122}$

Sweet Home suggests two categories of actions that would trigger the adverse modification prohibition but that would not be prohibited as takes. ${ }^{123}$ First, actions that adversely affect currently-unoccupied habitat are highly unlikely to cause a take but could qualify as prohibited adverse modifications. Second, actions that adversely affect habitat but have uncertain causal connections to harm to identifiable animals could fall solely under the adverse modification prohibition. In all likelihood, the latter class of actions, and perhaps also the former, also would fail to trigger the jeopardy prohibition, and the adverse modification prohibition alone would provide protection.

\footnotetext{
${ }^{121}$ That adverse modification would not be prohibited, however, unless the farmer needed a federal permit or funding for his actions.

122515 U.S. at 713.

${ }^{123}$ See also Arizona Cattle Growers' Ass'n v. U.S. Fish and Wildlife Serv., 273 F.3d 1229, 1238 (9th Cir. 2001) ("mere habitat degradation is not always sufficient to equal harm").
} 


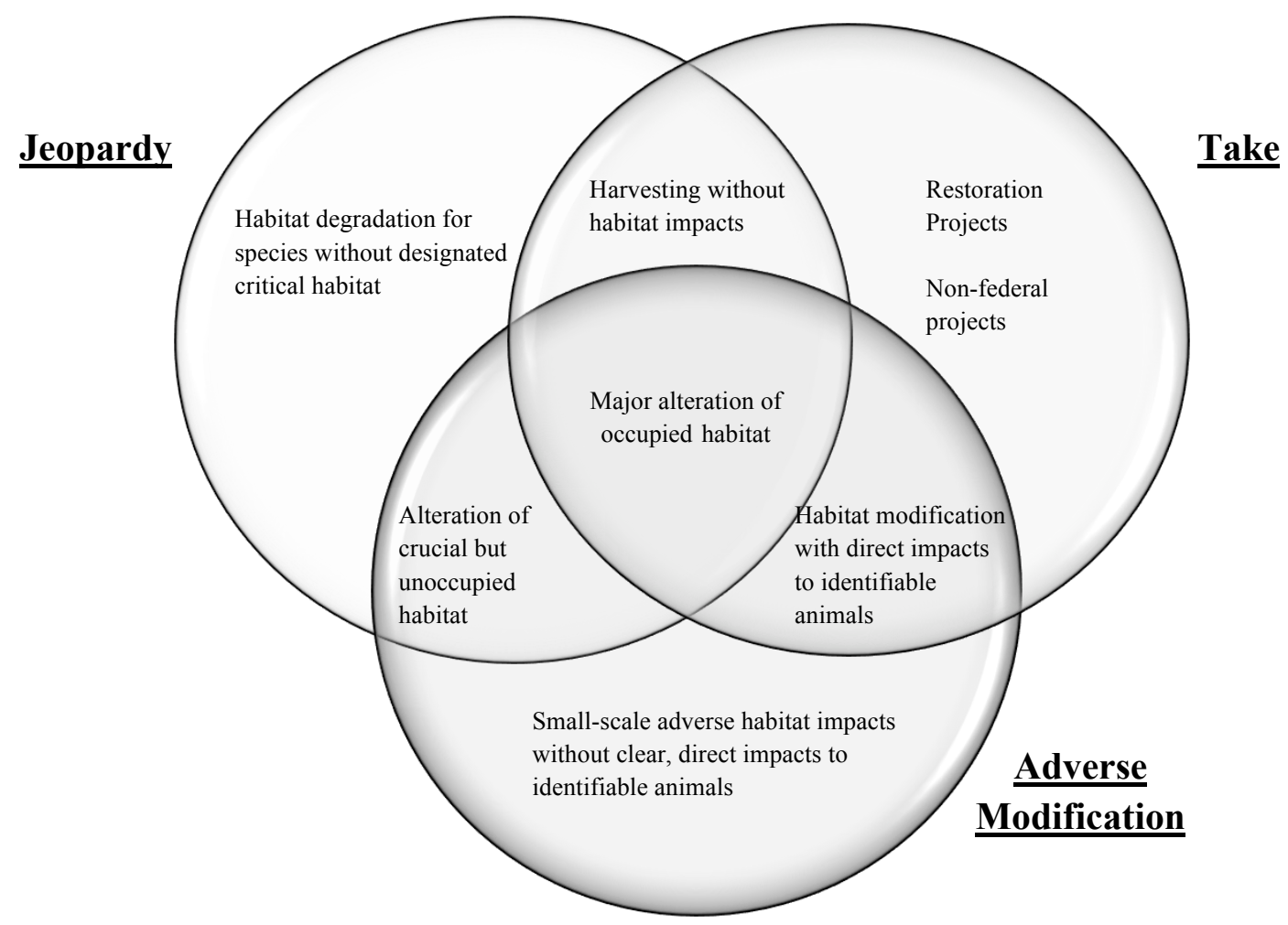

Figure 1: The ESA's Prohibitions

This diagram shows types of actions to which each of the ESA's regulatory prohibitions would apply. It also illustrates areas of potential overlap and, based on the plain language of the statute, unique application.

At first blush, these categories of actions to which the adverse modification provision alone applies might seem trivial. ${ }^{124}$ In actuality, they are probably enormous. ${ }^{125}$ Two examples illustrate their potential scope.

The first is climate change. Scientists know that every action that increases greenhouse gas emissions contributes to climate change, ${ }^{126}$ and they know that climate change is a primary threat to polar bear habitat (and habitat for thousands of other species). ${ }^{127}$ They cannot possibly

${ }^{124}$ See, e.g., Thompson, supra note 85, at 1141 (explaining why the critical habitat provisions rarely assume independent significance).

${ }^{125}$ See generally Odum, supra note 10, at 728 ("Each threatened and endangered species, with a few exceptions, owes its special status to series of small decisions.").

${ }^{126}$ Carbon dioxide and several other major greenhouse gases are long-lasting and well-mixed, which means that global emissions become blended together. See InTERgovernmental PANEl on Climate Change, Climate CHANGE 2007: THE PHYSICAL SCIENCE BASIS 138-39 (2007). The extent of climate change therefore is largely a function of global aggregate emissions, and any emissions that add to that aggregate level influence the extent of change.

${ }^{127}$ See Determination of Threatened Status for the Polar Bear (Ursus maritimus) Throughout Its Range, 73 Fed. Reg. 28212, 28292-93 (May 15, 2008); IPCC, supra note 126, at 11 (summarizing threats to species generally). 
say, however, which coal-fired power plant will kill which individual bears or what increment of harm that new plant will cause, for all global emissions become mixed, and one can no more explain which puffs of carbon dioxide will kill bears than one can identify a particular vote that won a national election. ${ }^{128}$ Scientists therefore know that greenhouse gas-emitting projects are adversely affecting critical habitat, but it is much harder to say that those projects are jeopardizing specific species or taking identifiable individual animals. Consequently, the critical habitat provisions alone would seem to apply to the many federal actions authorizing, permitting, or directly causing increases in greenhouse gas emissions.

A second example involves the water quality impacts of urbanization. Many scientific studies have documented a negative causal relationship between urban development and water quality degradation, particularly in small urban watersheds. ${ }^{129}$ The problem is caused not just by development adjacent to or in the waterway, but also by the increasing extent of impervious surfaces throughout the watershed, for every new development increases pollutant loading, alters flow patterns, and helps change the configuration of the stream. ${ }^{130}$ Assigning a specific increment of stream degradation to one project is likely to be impossible, for stream health usually reflects the intertwined influence of many stressors, ${ }^{131}$ and attributing jeopardy or a take to a particular development project would be quite difficult. But scientists can say with confidence that each new road, mall, or subdivision degrades aquatic habitat. ${ }^{132}$ If that habitat is

\footnotetext{
128 See Ruhl, supra note 54, at 17-23.

${ }^{129}$ See Dave Owen, Urbanization, Water Quality, and the Regulated Landscape, 82 COLO. L. REV. (2011) (summarizing this research).

${ }^{130}$ See Christopher J. Walsh et al., The Urban Stream Syndrome: Current Knowledge and the Search for a Cure, 24 J. N. AM. BENTHOLOGICAL SOC'Y 706, 707-08 (2005); CTR. FOR WATERSHED ProteCTION, IMPACTS OF IMPERVIOUS COVER ON AQUATIC SYSTEMS (2003).

${ }_{131}$ See Owen, supra note 129, at __. _.

${ }^{132}$ See Comm. on Reducing Stormwater Discharge Contributions to WATER Pollution, NAT’L RESEARCH COUNCIL, URBAN STORMWATER MANAGEMENT IN THE UNITED STATES 207 (2009) ("there is a nearuniversal negative association between biological assemblages in streams and increasing urbanization").
} 
designated as critical — and in some parts of the country, thousands of stream miles in urbanizing areas are so designated ${ }^{133}$ — the adverse modification prohibition again should apply.

For some of the most extensive threats to species habitat, then, the adverse modification prohibition seems to be the ESA's primary answer. Indeed, because of this unique role, and because of the pervasive challenges of incremental environmental degradation, it looks like one of the most powerful and important levers in all of environmental law.

\section{Methodology}

While in theory the critical habitat provisions should be very important, practice and theory can diverge. To gain a better sense of how FWS and NMFS actually implement the critical habitat provision, I pursued a series of inquiries. Those inquiries focused on several of the key points at which the critical habitat protections might exert some effect.

One key decision point is the consulting service's determination about whether or not a project will cause adverse modification or jeopardy. To track those outcomes, I reviewed almost $^{134}$ all biological opinions prepared for threatened or endangered fish species between 2005 and 2009. ${ }^{135}$ That group included 4,048 opinions. ${ }^{136}$ For each opinion, I tracked the

\footnotetext{
${ }^{133}$ See Critical Habitat Portal, supra note Error! Bookmark not defined. (showing designated habitat). Much of the designated habitat includes stream corridors in developing areas.

${ }^{134}$ Some opinions were available on line, and the rest I obtained through Freedom of Information Act requests. The Sacramento field office of the Fish and Wildlife Service was unable to locate nineteen biological opinions. Several field offices in FWS' Mountain/Prairie region chose to fill out a results table rather than directly providing documents. The results for those Mountain/Prairie region biological opinions are included in the study, but I have not seen the original documents. I also eliminated a few biological opinions for which the pdf files were incomplete.

${ }^{135}$ I limited the inquiry to fish species in an attempt to narrow the number of biological opinions. The fiveyear period post-dates the services' abandonment of the legally flawed regulatory definition of adverse modification. It also had the incidental benefit of including more electronically-available documents.

${ }^{136}$ NMFS issued 2,963 of the opinions and the Fish and Wildlife Service issued 1,085. Many biological opinion documents address more than one species, and some of those documents find jeopardy or adverse modification for some species but not others. In determining this overall number, and in performing the calculations described below, I counted each species-specific opinion as an independent biological opinion. Thus, if a single
} 
project type, action agency, species affected, jeopardy determination, adverse modification determination, whether critical habitat had been designated for the species, and, if critical habitat had been designated, whether the action area ${ }^{137}$ included designated critical habitat.

Because of the large pool of biological opinions, this initial review was necessarily limited to tracking a few specific parameters. To zero in on potential effects, I then looked more closely at three sets of biological opinions. The sets collectively contained 138 biological opinions. I began with coho salmon, a species with four separately-listed "evolutionarily significant units." ${ }^{\prime 138}$ During the study period, three of those units had designated critical habitat and the fourth did not. ${ }^{139}$ For each biological opinion, I recorded whether the services predicted a net positive, negative, or neutral or unclear impact on the species' habitat; ${ }^{140}$ whether NMFS anticipated take, and, if so, whether habitat modification was a predicted cause of take; and whether NMFS found jeopardy or adverse modification. I also performed a qualitative review of the conditions NMFS imposed upon the projects. ${ }^{141}$ I then completed similar comparisons for two other species sets: first, Rio Grande silvery minnow and Gila topminnow; and then all fish species under the jurisdiction of the FWS's Oregon field office. ${ }^{142}$ The former two species,

document addressed one project's impacts on four different listed species, I counted that document as four biological opinions.

${ }^{137}$ The services define the "action area" as the area affected by an action. It can be larger than the project footprint. See CONSUlTATION HANDBOOK, supra note 72, at 4-17.

${ }^{138}$ See Northwest Regional Office, NOAA's National Marine Fisheries Service, Coho Salmon (Oncorhynchus kisutch), at http://www.nwr.noaa.gov/ESA-Salmon-Listings/Salmon-Populations/Coho/ (last checked January 16,2011 ). To avoid attributing to coho protection measures that were designed primarily to benefit other species, I eliminated biological opinions that also included consultations on other listed species.

${ }^{139} I d$.

${ }^{140}$ Some biological opinions expressed conclusions on this question, and in others the expected effect was obvious from the analysis. If the expected net effect was not obvious or was ambiguously described, I treated the aggregate effect as neutral or uncertain.

${ }^{141}$ While reviewing the biological opinions, I tracked the number of RPMs imposed. But for several reasons, I decided these numbers were not meaningful. First, an RPM is just one of the many ways in which consultation can lead to changes in projects, see supra notes 69-77 and accompanying text, and a small number of RPMs may just indicate that other approaches were instead being used. Second, the number of RPMs may not correspond with their stringency. A single, simple prohibition may sometimes be more protective than a complex set of mitigation measures.

${ }^{142}$ I selected Oregon because the state has several fish species with critical habitat and several without. 
though handled by different FWS field offices, have somewhat similar biological needs and face somewhat similar threats, but the Rio Grande silvery minnow has designated critical habitat while the Gila topminnow does not. ${ }^{143}$ The latter group includes species both with and without critical habitat, all of them addressed by one field office. My goal, again, was to assess whether critical habitat designations correlated with any difference in the services' approaches to habitat protection.

Because all consultation processes occur in the shadow of judicial review, I also reviewed cases. The set of cases addressing the adverse modification prohibition is still surprisingly small, given the ESA's reputation as a spawning ground for litigation, and I reviewed all cases, both published and unpublished, available on Lexis or Westlaw. ${ }^{144}$

Finally, because I suspected that the paper record would tell only a partial story, I interviewed FWS and NMFS staff. ${ }^{145}$ The interviewees were all biologists, most with some level of supervisory responsibility over biological opinion preparation. All were career staff rather than political appointees. All of the interviews were semi-structured. ${ }^{146}$ I promised anonymity to all interviewees.

Because critical habitat is a rather controversial subject, a few words are in order about what I did not do. This study does not directly assess how action agencies and private

\footnotetext{
${ }^{143}$ See U.S. Fish and Wildlife Service, Species Profile, Rio Grande Silvery minnow (Hybognathus amarus), at http://ecos.fws.gov/speciesProfile/profile/speciesProfile.action?spcode=E07I\#crithab (last checked January 11, 2011); U.S. Fish and Wildlife Service, Species Profile, Gila topminnow (Poeciliopsis occidentalis), at http://ecos.fws.gov/speciesProfile/profile/speciesProfile.action?spcode=E00C. Both species primarily inhabit backwater and sidechannel habitats within desert river systems, and both are threatened by dewatering of rivers, increasing pollution levels, and changes in river channel structure. See U.S. FiSH AND WiLDLIFE SERVICE, Biological Opinion: ONGOING GraZING FOR Three AllotMENTS ON THE TONTO NATIONAL ForeSt 10 (2009) (describing Gila topminnow habitat needs and threats); U.S. FISH AND WILDLIFE SERVICE, BIOLOGICAL OPINION ON THE EfFects of THE Tiffany Sediment Plug Removal 7-8, 11-12 (2005) (describing Rio Grande Silvery Minnow habitat needs and threats to that habitat).

${ }^{144}$ See infra Part IV.C (discussing twenty cases).

${ }^{145}$ Most interviews were by telephone, but several biologists responded by email. One biologist distributed the questions to all field offices in her region and then sent me a compilation of their answers, which we then discussed in a telephone call.

${ }^{146}$ My standard questions appear in Table 2.
} 
landowners respond to critical habitat designations. I did ask agency staff about their perceptions of the reactions of regulated parties, but my focus was on the implementation of the provisions by the services and on review of that implementation by the courts. This study therefore is not, and should not be interpreted as, a definitive study of the effects of critical habitat designations, though its results should assist anyone pursuing such an inquiry.

\section{Results: The Prohibition in Practice}

\section{A. Jeopardy and Adverse Modification Determinations}

The final product of a formal consultation process is a biological opinion, and the crux of a biological opinion is its determination about whether the proposed action is likely to adversely modify critical habitat or to jeopardize listed species. One key focus of my analysis therefore was on the frequency of jeopardy and adverse modification determinations.

On this question, I was not exploring uncharted waters. While no past study has attempted to isolate the effect of critical habitat designations upon these outcomes, several have reviewed the frequency of jeopardy and adverse modification determinations. ${ }^{147}$ All of these studies have found that both jeopardy and adverse modification determinations are quite rare. The primary reason is straightforward: the action agency and the consulting agency have many opportunities to revise the proposed action and avoid a jeopardy or adverse modification determination, and they usually take advantage of these opportunities. ${ }^{148}$ Who accommodates

${ }^{147}$ Houck, note 24, at 319-20; DAVID HoskinS ET AL., FOR CONSERVING LiSTED SPECIES, TALK IS Cheaper than We Think: The Consultation Process Under the EndANGered SpeCiEs Act (1994); U.S. Gen. ACCOUNTING OfFICE, ENDANGERED SPECIES ACT: TYPES AND NuMBers OF IMPLEMENTING ACTIONS 31-32 (1992) ("over 90 percent of the biological opinions issued by FWS/NMFS during the past 5 fiscal years have found that the proposed action would not likely place a listed species in jeopardy"); GENERAL ACCOUNTING OFFICE, ENDANGERED SPECIES: Limited EFFECT OF CONSUltation REQUiREMENTS ON WESTERN WATER PROJECTS (1987).

${ }^{148}$ See General AcCounting Office, Endangered Species: More Federal Management AtTention Is NEEDED to IMPROVE THE CONSULTATION PROCESS 19-20 (2004) (describing measures taken by the agencies to increase collaboration and avoid conflict during consultation processes). One biologist told me that the services 
whom in those negotiations is a more difficult question to answer; some studies assert that the rarity of jeopardy or adverse modification decisions represents conflict avoidance primarily on the part of the services, ${ }^{149}$ but there also is evidence that action agencies will go to great lengths to avoid a jeopardy determination. ${ }^{150}$ Either way, the past studies do demonstrate that some accommodation usually occurs.

Like the prior studies, I found that jeopardy and adverse modification determinations are rare. Within the set of biological opinions that I reviewed, the FWS found jeopardy $7.2 \%$ of the time and adverse modification for $6.6 \%$ of eligible opinions. ${ }^{151}$ Those numbers include the opinions of a Utah field office that from 2005 through November, 2008 issued jeopardy and adverse modifications with anomalous frequency. With the Utah opinions eliminated, the percentages are $2.4 \%$ and $0.083 \%$. For NMFS, the percentages were lower: $0.54 \%$ for jeopardy and $0.53 \%$ for adverse modification. Interestingly, the percentages were different under the Bush and Obama administrations. From January 20, 2009 through the end of that year, neither FWS nor NMFS issued a single jeopardy or adverse modification decision for any fish species. ${ }^{152}$ These results suggest subtle differences between agencies and administrations, ${ }^{153}$ but

occasionally send draft jeopardy/adverse modification opinions to action agencies. Action agencies usually respond to these draft jeopardy/adverse modification opinions by changing the project, removing the need for a jeopardy or adverse modification determination. NMFS Biologist Interview, Nov. 16, 2010.

${ }^{149}$ Houck, supra note 24, at 319-21.

${ }^{150}$ See GAO, supra note 148, at 49 ("action agencies typically do quite a bit to avoid getting such an opinion").

${ }^{151}$ By eligible opinions I mean opinions for species that actually have designated critical habitat.

${ }^{152}$ I do not know why this difference exists. Possible explanations are that the Obama Administration has discouraged jeopardy and adverse modification opinions even more than the Bush Administration did, that the Obama Administration has encouraged action agencies to propose fewer harmful actions or to be more accommodating of proposed changes, or that the Obama Administration is better at resolving interagency conflict.

${ }^{153}$ The differences between NMFS and FWS in the frequency of jeopardy and adverse modification findings are both significant at the 99\% level (for jeopardy: Pearson chi-square: 155.232, degrees of freedom: 1, $\mathrm{P}=0.000$; for adverse modification Pearson chi-square: 97.575, degrees of freedom: $1, \mathrm{P}=0.000$ ). The differences between NMFS and FWS in the Bush and Obama Administration are not significant at the $95 \%$ level but are significant at the $90 \%$ level (for jeopardy: Pearson chi-square: 3.709 , degrees of freedom: $1, \mathrm{P}=0.054$; for adverse modification: Pearson chi-square: 3.714 , degrees of freedom: $1, \mathrm{P}=0.054$ ). In other words, one can say with $90 \%$ confidence that the Obama Administration is less likely to find adverse modification or jeopardy than the Bush Administration. 
the essential point is that for both agencies and administrations, jeopardy and adverse modification determinations are rare.

Table 1: Frequency of jeopardy and adverse modification determinations

\begin{tabular}{|c|c|c|c|c|c|c|}
\hline & \multicolumn{3}{|c|}{$\begin{array}{c}\text { NMFS } \\
\text { (2962 opinions total) }\end{array}$} & \multicolumn{3}{|c|}{$\begin{array}{c}\text { FWS } \\
\text { (1085 opinions total; } 786 \text { non-Utah opinions) }\end{array}$} \\
\hline & Total & $\begin{array}{l}\text { Bush } \\
\text { Admin. }\end{array}$ & $\begin{array}{l}\text { Obama } \\
\text { Admin. }\end{array}$ & Total & $\begin{array}{l}\text { Bush } \\
\text { Admin. }\end{array}$ & $\begin{array}{l}\text { Obama } \\
\text { Admin. }\end{array}$ \\
\hline $\begin{array}{l}\text { Frequency of } \mathrm{J} \\
\text { determinations }\end{array}$ & \multirow[t]{2}{*}{$0.54 \%$} & \multirow[t]{2}{*}{$0.66 \%$} & \multirow[t]{2}{*}{$0 \%$} & $7.2 \%$ & $8.5 \%$ & $0 \%$ \\
\hline w/o Utah & & & & $2.4 \%$ & $2.9 \%$ & $0 \%$ \\
\hline $\begin{array}{l}\text { Frequency of AM } \\
\text { determinations }\end{array}$ & \multirow[t]{2}{*}{$0.53 \%$} & \multirow[t]{2}{*}{$0.68 \%$} & \multirow[t]{2}{*}{$0 \%$} & $6.6 \%$ & $8.2 \%$ & $0 \%$ \\
\hline w/o Utah & & & & $0.083 \%$ & $1.0 \%$ & $0 \%$ \\
\hline $\begin{array}{l}\text { \# AM determinations } \\
\text { w/o jeopardy }\end{array}$ & 0 & 0 & 0 & 0 & 0 & 0 \\
\hline $\begin{array}{l}\text { Jeopardy percentage } \\
\text { for species } w / \mathrm{o} \mathrm{CH}\end{array}$ & $0.13 \%$ & $0.15 \%$ & $0 \%$ & $3.7 \%$ & $4 \%$ & $0 \%$ \\
\hline $\begin{array}{l}\text { Jeopardy percentage } \\
\text { for species } \mathrm{w} / \mathrm{CH}\end{array}$ & \multirow[t]{2}{*}{$0.68 \%$} & \multirow[t]{2}{*}{$0.87 \%$} & \multirow[t]{2}{*}{$0 \%$} & $7.9 \%$ & $11 \%$ & $0 \%$ \\
\hline w/o Utah & & & & $3.2 \%$ & $3.9 \%$ & $0 \%$ \\
\hline
\end{tabular}

I also evaluated how frequently an adverse modification determination played an independent role in a negative biological opinion. As discussed above, the plain language of the statute suggests that the adverse modification prohibition would often have independent effect, for the set of federal actions that adversely affect habitat without clearly jeopardizing species would seem to be quite large. ${ }^{154}$ And following the Gifford Pinchot Task Force decision, ${ }^{155}$ the services have consistently claimed they are ignoring their regulatory definition of adverse modification — a definition that seemed to allow some incremental degradation — and focusing solely on the statutory language. ${ }^{156}$ But my data set did not include a single opinion in which either NMFS or FWS found jeopardy without finding adverse modification. Instead, the agencies have treated the class of actions that adversely modifies habitat without also causing jeopardy as a null set.

\footnotetext{
${ }^{154}$ See supra notes $125-133$ and accompanying text.

${ }^{155}$ Gifford Pinchot Task Force v. U.S. Fish and Wildlife Serv., 378 F.3d 1059, 1069-71 (9th Cir. 2004).

${ }^{156}$ See supra notes $114-115$ and accompanying text.
} 
One might hypothesize that perhaps the services were reluctant to let adverse modification findings stand on their own, and therefore added jeopardy determinations when they were already leaning toward adverse modification findings. There is some statistical evidence consistent with this hypothesis. ${ }^{157}$ NMFS did find jeopardy more frequently for species with designated critical habitat, and the difference, while not significant at the traditional 95\% level, is significant at a $90 \%$ level. ${ }^{158}$ In interviews, a few biologists thought such an effect was possible, whether because a critical habitat designation increased focus on habitat needs or because the opinions' authors were reluctant to try to explain an adverse modification finding without an accompanying jeopardy finding. ${ }^{159}$ But other biologists expected no such effect, and neither the interviews nor the statistics suggest that the effect, if it does exist, is anything more than a subtle influence potentially changing a tiny percentage of outcomes. ${ }^{160}$

Closer examination of the subsets of opinions confirmed that critical habitat designations had little effect on regulatory outcomes. In forty-four of the 138 opinions, the proposed action was expected to have net adverse effects on habitat. ${ }^{161}$ Some of the anticipated habitat effects seemed substantial and others minor, but by at least one key measure, almost all were meaningful and discernable: in over eighty percent of these opinions, the service determined that the habitat alteration would cause or contribute to "take" of the relevant listed species. ${ }^{162}$ Yet not

${ }^{157}$ Critical habitat also may be designated more often for species in greater danger of extinction, and the increased frequency of jeopardy determinations might reflect the gravity of threats rather than an independent effect of critical habitat designations.

${ }^{158}$ For the FWS, there is no statistical evidence supporting this hypothesis. With Utah opinions eliminated from the analysis, the jeopardy percentages for species with and without critical habitat are almost the same. See Table 1, supra.

${ }^{159}$ See infra Table 3.

${ }^{160} \mathrm{Id}$.

${ }^{161} \mathrm{Id}$.

${ }^{162}$ Several of the remaining opinions were unclear about whether habitat modification would contribute to the take. 
one of these opinions found that the project would cause jeopardy or adverse modification, and the presence or absence of a critical habitat designation had no apparent effect upon the outcome.

Table 2: Frequency of jeopardy, adverse modification, and take findings for selected subsets of biological opinions

\begin{tabular}{|c|c|c|c|c|c|c|}
\hline $\begin{array}{l}\text { Species } \\
\text { group }\end{array}$ & $\begin{array}{l}\text { Total \# } \\
\text { opinions }\end{array}$ & $\begin{array}{l}\text { Percent } \\
\text { predicting } \\
\text { positive, } \\
\text { negative, } \\
\text { neutral } \\
\text { /uncertain } \\
\text { habitat trends }\end{array}$ & $\mathrm{J}$ findings & AM findings & $\begin{array}{l}\text { Percent (for } \\
\text { opinions predicting } \\
\text { negative habitat } \\
\text { trend and for all } \\
\text { opinions) finding } \\
\text { take partly or } \\
\text { entirely due to } \\
\text { habitat } \\
\text { modification }\end{array}$ & $\begin{array}{l}\text { Percent imposing } \\
\text { reasonable and } \\
\text { prudent measures }\end{array}$ \\
\hline Coho $(\mathrm{CH})$ & 47 & $\begin{array}{l}32 \%+ \\
36 \%- \\
32 \% ?\end{array}$ & 0 & 0 & $\begin{array}{c}94 \%- \\
94 \% \text { overall }\end{array}$ & $96 \%$ \\
\hline $\begin{array}{l}\text { Coho (no } \\
\mathrm{CH} \text { ) }\end{array}$ & 13 & $\begin{array}{l}46 \%+ \\
23 \%- \\
31 \%=/ ?\end{array}$ & 0 & 0 & $\begin{array}{c}100 \% \text { - } \\
80 \% \text { overall }\end{array}$ & $92 \%$ \\
\hline $\begin{array}{l}\text { Rio Grande } \\
\text { silvery } \\
\text { minnow } \\
(\mathrm{CH})\end{array}$ & 18 & $\begin{array}{l}56 \%+ \\
39 \%- \\
6 \%=/ ?\end{array}$ & 0 & 0 & $\begin{array}{c}14 \%- \\
56 \% \text { overall }\end{array}$ & $100 \%$ \\
\hline $\begin{array}{l}\text { Gila } \\
\text { topminnow } \\
\text { (no } \mathrm{CH} \text { ) }\end{array}$ & 9 & $\begin{array}{l}44 \%+ \\
22 \%- \\
33 \%=/ ?\end{array}$ & 0 & 0 & $\begin{array}{c}100 \% \text { - } \\
89 \% \text { overall }\end{array}$ & $89 \%$ \\
\hline Oregon $(\mathrm{CH})$ & 18 & $\begin{array}{l}56 \%+ \\
39 \%- \\
6 \%=/ ?\end{array}$ & 0 & 0 & $\begin{array}{c}100 \% \text { - } \\
94 \% \text { overall }\end{array}$ & $100 \%$ \\
\hline $\begin{array}{l}\text { Oregon (no } \\
\mathrm{CH} \text { ) }\end{array}$ & 29 & $\begin{array}{l}48 \%+ \\
28 \%- \\
24 \%=/ ?\end{array}$ & 0 & 0 & $\begin{array}{c}87.5 \%-^{*} \\
66 \% \text { overall }\end{array}$ & $100 \%$ \\
\hline $\begin{array}{l}\text { Oregon } \\
\text { (mixed) }\end{array}$ & 4 & $\begin{array}{l}75 \%+ \\
0 \%- \\
25 \% ?\end{array}$ & 0 & 0 & $\begin{array}{c}100 \%- \\
75 \% \text { overall }\end{array}$ & $100 \%$ \\
\hline $\begin{array}{l}\text { All non-CH } \\
\text { opinions }\end{array}$ & 51 & $\begin{array}{l}47 \%+ \\
25.5 \%- \\
27.5 \%=/ ?\end{array}$ & 0 & 0 & $\begin{array}{c}92 \%-* \\
69 \% \text { overall }\end{array}$ & $90 \%$ \\
\hline $\begin{array}{l}\text { All CH } \\
\text { opinions }\end{array}$ & 83 & $\begin{array}{l}42 \%+ \\
37 \%- \\
20 \%=/ ?\end{array}$ & 0 & 0 & $\begin{array}{c}81 \%- \\
86 \% \text { overall }\end{array}$ & $98 \%$ \\
\hline
\end{tabular}

Nor could I discern any important difference in the method of analysis. Some differences do appear; biological opinions for projects affecting critical habitat do always include paragraphs discussing those effects, and in the pool of opinions I reviewed closely, they also always included a finding of no adverse modification. But jeopardy discussions also consistently 
addressed habitat, and the adverse modification analyses often seemed like derivative appendages to the jeopardy analyses. That appearance is entirely consistent with what one biologist described as a prevailing attitude toward these analyses: "it's like, oh, we have to do the adverse mod... it's just another thing we have to do.",163

The opinions also indicate why the agencies were never finding adverse modification, even where projects clearly would adversely affect designated critical habitat and the effects were of sufficient scale to harm or even kill individual animals. Quite simply, the services do not construe the adverse modification prohibition as applying to minor alterations to habitat. And in the 138 opinions I closely reviewed, all negative alterations were described-sometimes convincingly, sometimes not ${ }^{164}$-as minor. The biological opinions offered a variety of justifications for these conclusions, but all essentially amount to the claim that the project would only affect a small portion of the species' critical habitat, and therefore, in the grand scheme of things, would not really matter. ${ }^{165}$ Sometimes the biological opinions offered that rationale

${ }^{163}$ FWS Biologist Interview, January 26, 2010.

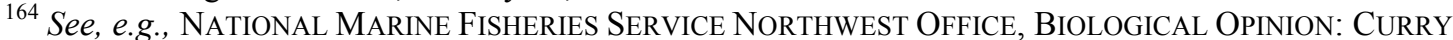
COUNTY RoAds DEPARTMENT AND RINGER GRAVEl Mining IN HunTER CREEK 14-20 (2005) (finding no adverse modification despite concluding that a project would "alter approximately 2,450 feet of streambank... used by juvenile coho salmon as rearing habitat;" would result in "reduction in production of desirable macroinvertebrate species in 1,500 feet of stream and a reduction in desirable prey to rearing SONC coho salmon juveniles"); National Marine Fisheries Service Northwest OfFice, Biological Opinion: Tidewater Contractors GraVEl Mining, ROgUe RIVER ESTUARY 12 (2006) (finding no adverse modification for a project that "will decrease habitat suitability and likely result in reduced use of these two acres of the river by coho salmon. The project will disrupt the normal behavior patterns of individuals that would use these areas, and will delay the recovery of the habitat characteristics important for high water refuge."); BUCKMAN DIVERSION BIOLOGICAL OPINION, supra note 116, at 42-43 (2007) (finding no adverse modification for a water project that would reduce flows in the Rio Grande). The opinion noted that

[t]his reduction in flows contributes to an increased risk of river drying (either in timing of a drying event or the extent of that event). Even without a drying event, the reduction in flows affects the total wetted area, water depth, sediment transport, and structure of the aquatic habitats (pools, runs, riffles). Reduced water quality may also be a concern, particularly as there would be less water for dilution of waste water treatment plant (WWTP) inflows. Primary constituent elements of designated critical habitat are also adversely affected.

Id. at 33; see also id. at 33-41 (describing in detail the impacts, which the conclusion dismissed as "minimal").

${ }^{165}$ In general, the services asked whether the particular project's effects would be discernible at some regional scale. But they rarely considered whether the project, in combination with other similar projects, would have a discernible effect. See, e.g., National Marine Fisheries Service Northwest Office, Biological OPINION: BOERSMA GRAVEL PIT STABILIZATION, APPLEGATE RIVER 15 (2007) (finding no adverse modification for 
within a few paragraphs of a cumulative effects analysis acknowledging that the species' habitat was being degraded, and that the degradation was occurring through the incremental effects of small habitat alterations, but the apparent tension between their reasoning and the broader negative trend was never acknowledged. ${ }^{166}$

The sets of biological opinions also contain a gap that indicates, perhaps more tellingly than anything affirmatively said, the limited actual reach of the adverse modification prohibition. Part II of this Article explained that the adverse modification prohibition would appear, on paper, to be the ESA's primary mechanism for addressing federal actions increasing greenhouse gas emissions or accelerating the water quality impacts of urbanization. ${ }^{167}$ A person well-versed in statutory requirements but somewhat naïve about practical realities therefore might expect to see many biological opinions addressing new greenhouse gas sources and new urban development. ${ }^{168}$ But the former type of biological opinion does not appear in either data set. The latter type does, but far less frequently than one might expect. The services consult when projects will abut, intrude into, or cross rivers or streams inhabited by listed species, but development projects not directly adjacent to waterways rarely are subjected to formal

a project with negative habitat impacts "it will only affect less than $1 \%$ of the Applegate River in the Lower Applegate River 5th Field watershed"); U.S. Fish and Wildlife Service, New MeXico Ecological Services Field OfFice, Biological Opinion: EfFects of the Drain Unit 7 EXTENSION PRIORITY Site Project 20-21 (2007) (finding no adverse modification for a project with adverse habitat impacts "because the impacts will be temporary and occur in a very small area relative to the overall critical habitat designation").

${ }^{166}$ See, e.g., TidewATER CONTRACTORS GRAVEL Mining BiOLOGICAL OPINION, supra note 164, at 16 (finding no adverse modification for a gravel mining project just after noting that "[a]s the human population in the action area continues to grow, demand for agricultural, commercial, or residential development, as well as gravel for roads and concrete, is also likely to grow. The effects of new development caused by that demand are likely to reduce the conservation value of the habitat within the action area"); DRAIN UNIT 7 EXTENSION PRIORITY SITE BIOLOGICAL OPINION, supra note 165, at 21 (finding no adverse modification for a habitat-degrading project within a few paragraphs of noting that other activities "will continue to threaten the survival and recovery of the silvery minnow by reducing the quantity and quality of habitat through continuation and expansion of habitat degrading actions").

${ }_{168}^{167}$ See supra notes $125-133$ and accompanying text.

${ }^{168}$ Many development projects do not require federal funding or authorization and therefore would not be covered by section 7. But many development projects do require federal wetlands permits, and federal funding also supports lots of road building, so the set of projects potentially subject to regulatory coverage still should be large. 
consultation, notwithstanding their widely-understood impacts upon aquatic species' habitat. ${ }^{169}$ Two major classes of activities collectively causing major habitat degradation therefore proceed with essentially no ESA-based regulation at all.

\section{B. Project modifications}

While the jeopardy and adverse modification determinations might seem like the heart of the biological opinion, they are not the only important component. Indeed, because of the rarity of jeopardy and adverse modification determinations, the most important content probably lies elsewhere. In particular, even when a biological opinion determines that a project is not likely to adversely modify critical habitat or cause jeopardy, the opinion still will often contain a list of modifications of and conditions for proceeding with the project. I therefore also reviewed these modifying conditions, first to assess whether they seemed different when critical habitat was at issue, and second to assess what they revealed about the services' approaches to habitat protection.

1. The prevalence of take findings and conditions

As discussed in Part II, one might expect the critical habitat provisions to provide more habitat protection than the take provision. The take provision applies only when an action proximately causes harm to protected animals. ${ }^{170}$ That seems to require a more complex showing of causation than would be necessary to demonstrate an adverse modification to critical habitat, for the latter showing would only require demonstration of harm to habitat. But even as the services routinely decline to find adverse modification, they almost always predict that proposed projects will cause take of listed species, and they usually find that the take will be at

\footnotetext{
${ }^{169}$ The set of 138 closely-reviewed opinions included no consultations addressing the impacts of impervious cover at locations removed from the waterways, even though the cumulative impacts discussion in some of those opinions - particularly those for coho salmon - routinely identified urbanization as a threat. See, e.g., Tidewater CONTRACTORS GRAVEl Mining Biological Opinion, supra note 164, at 16.

${ }^{170}$ See supra notes 117-123 and accompanying text (discussing the Sweet Home decision).
} 
least partly due to habitat modifications. ${ }^{171}$ Of the subset of biological opinions I reviewed in detail, ninety-six percent anticipated take, and eighty-three percent anticipated take through habitat modification. ${ }^{172}$ Eighty-four percent of the opinions that anticipated negative aggregate effects on habitat found that habitat modifications would cause or contribute to takes. ${ }^{173}$ Even when the services anticipated a net benefit to species - and quite often they did, for many of the consultations involved restoration projects—-take findings still were routine. ${ }^{174}$

The services also almost always attempted to minimize the habitat degradation that led to take. In almost every one of the opinions that anticipated take through habitat modification, the relevant service tried to limit that take by imposing "reasonable and prudent measures" at least partially designed to protect habitat. They also imposed "conservation measures" to similar effect. ${ }^{175}$ In addition to these measures, the services would often include "conservation recommendations," which are non-binding suggestions for additional actions that could benefit listed species. ${ }^{176}$ And while the biological opinions did not reveal these changes, biologists told me that the services routinely ask agencies to modify their project descriptions in ways designed to protect species. ${ }^{177}$

The nature of those conditions varies. For some species—typically salmonids ${ }^{178}$ - the conditions are usually quite detailed, often running for several pages and containing highly specific instructions on everything from replanting native vegetation to staffing the project with

${ }^{171}$ See infra Table 3.

${ }^{172}$ Id.

${ }^{173} I d$. The remaining seven opinions include one programmatic opinion, which left take findings to be made in subsequent project-specific biological opinions, and several opinions that did not clarify whether habitat modification was an anticipated cause of take.

174 Id. 143 , at 5 .

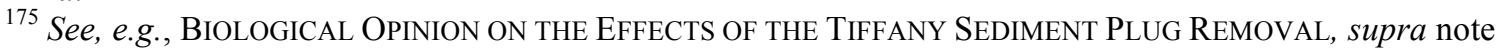

${ }^{176}$ See, e.g., id. at 27.

${ }^{177}$ See, e.g., FWS biologist interview, December 21, 2010 (explaining that FWS's "preference always is to get conservation up front.").

${ }^{178}$ Salmonids include salmon and trout species. Collectively they account for the majority of fish-related consultations. 
trained biologists. ${ }^{179}$ For other species, the conditions are much more general. ${ }^{180}$ The conditions also varied in the extent to which they were tailored to specific sites. Some were obviously created with one specific project in mind, ${ }^{181}$ but many reflected more generalized best management practices for the type of project and species at issue. Some of those best management practices appeared to have informally evolved through a series of consultations on similar projects, while others were memorialized in programmatic consultations or in written interagency agreements. ${ }^{182}$

Despite that variation, one common theme emerged: the services expected many of the conditions to provide significant benefits to the species. ${ }^{183}$ Sometimes the benefits would simply reduce the adverse impacts of the project, but with many projects the services anticipated that with the protective conditions in place, the project would actually benefit affected species. ${ }^{184}$ While a rigorous evaluation of the accuracy of those predictions is impossible without monitoring data and some knowledge of the specific context of each project, and also is beyond the competence of a legal researcher, the claims easily pass a straight-face test. Measures like replanting shade vegetation, re-engineering stream crossings to improve fish passage, isolating work areas, limiting work to seasons when listed fish species are less likely to be present, and

${ }^{179}$ See, e.g., NOAA's NATIONAL MARINE FiSHERIES SERVICE NORTHWEST REGION, BIOLOGICAL OPINION: EAst/WeSt Fork ILLINOIS RIVER BRIDGE REPLACEMENTS PROJECT 28-37 (2005) (nine pages specifying RPMs and implementing conditions).

${ }^{180}$ See, e.g., BUCKMAN DiVERsiOn BIOLOGICAL OPINION, supra note 116, at 44-45 (specifying one RPM with one term and condition requiring the future development of a strategy to minimize project impacts).

${ }^{181}$ See, e.g., NATIONAL MARINE FiSHERIES SERVICE NORTHWEST REGION, BIOLOGICAL OPINION: MiLlport SlOUgh BRIDGE Siletz RIVER 36 (2009) (providing detailed specifications for eelgrass restoration to compensate for habitat impacted by the project).

182 See, e.g., NATiOnal MARine Fisheries Service NorthweSt Region, Biological Opinion: Sucker Creek Bridge Replacement and Bank Stabilization Project 2 (2006) (describing conditions specified in an earlier programmatic biological opinion); NMFS biologist interview, November 16, 2010 (explaining that more than half of their consultations use standardized conditions, and describing this as a "very fruitful way to go" because of administrative efficiencies and because action agencies were willing to accept highly protective conditions). bombproof").

${ }^{183}$ E.g. NMFS Biologist Interview, November 16, 2010 (describing some of the conditions as "pretty much

184 See, e.g., National Marine Fisheries Service, Northwest Region, Conference OpiniOn: Fall CREeK CUlvert AND BRIDGE PROJECT (2005) (biological opinion for a roadway project coupled with substantial efforts to improve fish passage). 
requiring trained fish biologists to observe project implementation ${ }^{185}$ all seem likely to provide real benefits to species. ${ }^{186}$

2. The slight (but evolving) importance of critical habitat

The preceding discussion clearly demonstrates that section 7 consultations lead to habitat protection. But I found little evidence that critical habitat designations make any difference in the level of protection.

In reviewing biological opinions, I found no difference in approach for species with critical habitat and species without. For both categories of species, the agencies allowed habitatdegrading projects to proceed; for both categories, they imposed conditions designed to reduce, but not always eliminate, the extent of habitat impacts; for both categories, they used conservation requirements and reasonable and prudent measures to adjust projects; and within both categories the level of detail in the conditions varied. But a limited quantitative analysis reveals no clear trends, ${ }^{187}$ and qualitatively, the variations seem more closely related to species type and office location than to the critical habitat designation. Perhaps most tellingly, the biological opinions never mentioned protecting critical habitat as an independent justification for imposing conditions. My analysis does not prove that the conditions imposed for species with critical habitat and those imposed for species without are the same, for there could be subtle distinctions that a primarily-qualitative comparison would not pick up. But I found no affirmative documentary evidence that the agencies were using distinct approaches.

The interviews nevertheless suggested that critical habitat designations have some effects. Some, though not all, of the biologists believed that critical habitat designations slightly

${ }^{185}$ See, e.g., id. at 2-5, 23-30 (describing these and many other measures).

${ }^{186}$ The extent of the benefit is uncertain, however. See Lyman L. McDonald et al., Monitoring and Evaluation: Salmon Restoration in the Columbia River Basin, in RETURN TO THE RIVER: RESTORING SALMON TO THE COLUMBIA RIVER 571, 588 (Richard N. Williams ed. 2006) (noting uncertainties about restoration activities)

${ }^{187}$ See Table 2, supra. 
increased the likelihood that action agencies would engage in informal consultation prior to proceeding with projects. Some, though again not all, of the biologists thought that the process of designating critical habitat spurred the services to think more carefully about species' habitat needs, and that the resulting additional knowledge could help them develop more protective conditions. Many of the biologists thought that a critical habitat designation gave the services more leverage to negotiate habitat conditions. ${ }^{188}$ With one exception, ${ }^{189}$ none of the biologists thought the changes were large, and any assertion of major across-the-board effects would be difficult to reconcile with the biological opinions. But all thought that subtle effects do exist.

${ }^{188}$ E.g. E-mail from FWS biologist to author, November 24, 2010 ("The $\mathrm{CH}$ designation helped bring everyone to the table and gave me better leverage to negotiate some significant avoidance measures.").

${ }^{189}$ See NMFS Biologist interview, November 22, 2010 (stating the designations gave her "a stronger arm going into negotiations... it makes a really big difference.”). 
Table 3: Summary of agency biologist responses ${ }^{190}$

\begin{tabular}{|c|c|c|}
\hline Question & $\begin{array}{c}\text { Answers by the } \\
\text { numbers }\end{array}$ & Representative answers \\
\hline $\begin{array}{l}\text { Do you think } \mathrm{CH} \\
\text { designations affect the } \\
\text { frequency with which } \\
\text { action agencies engage in } \\
\text { informal consultations? }\end{array}$ & $\begin{array}{l}\text { Yes: } 2 \\
\text { Yes, slightly: } 4 \\
\text { Possibly: } 2 \\
\text { No: } 7\end{array}$ & $\begin{array}{l}\text { - A few biologists thought designations sensitize action agencies } \\
\text { to effects on habitat, leading to more consultations } \\
\text { - Several biologists perceived a change in the frequency of } \\
\text { informal consultations for unoccupied habitat }\end{array}$ \\
\hline $\begin{array}{l}\text { Do you think } \mathrm{CH} \\
\text { designations make } \\
\text { projects more likely to } \\
\text { proceed to formal } \\
\text { consultation? }\end{array}$ & $\begin{array}{l}\text { Yes: } 2 \\
\text { Yes, slightly: } 3 \\
\text { Possibly: } 2 \\
\text { No: } 8\end{array}$ & $\begin{array}{l}\text { - Several biologists mentioned consultations for unoccupied } \\
\text { habitat } \\
\text { - One biologist who said "no" noted that she was starting to } \\
\text { question that approach }\end{array}$ \\
\hline $\begin{array}{l}\text { Do you think CH } \\
\text { designations affect the } \\
\text { choice of conservation } \\
\text { measures? }\end{array}$ & $\begin{array}{l}\text { Yes: } 5 \\
\text { Maybe: } 2 \\
\text { Occasionally: } 3 \\
\text { No: } 5\end{array}$ & $\begin{array}{l}\text { - People are "more willing to negotiate and mitigate" } \\
\text { - "It makes a really big difference." } \\
\text { - "Maybe, but not much" } \\
\text { - "In any section } 7 \text { consultation, we strive to protect the species } \\
\text { and the ecosystem it depends upon." }\end{array}$ \\
\hline $\begin{array}{l}\text { Do you think CH } \\
\text { designations affect the } \\
\text { choice of RPMs? }\end{array}$ & $\begin{array}{l}\text { Yes: } 1 \\
\text { Possibly, or } \\
\text { occasionally: } 2 \\
\text { No: } 11\end{array}$ & $\begin{array}{l}\text { - Many biologists asserted that RPMs should focus on mitigating } \\
\text { take, not on independently protecting critical habitat } \\
\text { - Two biologists who said "no" thought that might change }\end{array}$ \\
\hline $\begin{array}{l}\text { Do you think CH } \\
\text { designations affect the } \\
\text { choice of RPAs? }\end{array}$ & $\begin{array}{l}\text { Yes: } 3 \\
\text { It should: } 1 \\
\text { Maybe: } 1 \\
\text { No: } 7 \\
\text { No experience: } 3\end{array}$ & $\begin{array}{l}\text { - If an RPA came specifically out of an adverse modification } \\
\text { determination, that would be a big deal }\end{array}$ \\
\hline $\begin{array}{l}\text { Do you think CH } \\
\text { designations increase the } \\
\text { likelihood of jeopardy } \\
\text { determinations? }\end{array}$ & $\begin{array}{l}\text { Yes: } 4 \\
\text { Maybe: } 2 \\
\text { Hard to say: } 1 \\
\text { No: } 5 \\
\text { No experience: } 3 \\
\end{array}$ & $\begin{array}{l}\text { - Some biologists thought designations increase focus on habitat, } \\
\text { which could change the outcome of the jeopardy analysis; } \\
\text { - Others argued that the jeopardy analysis was always focused on } \\
\text { habitat and expected no change in outcomes }\end{array}$ \\
\hline $\begin{array}{l}\text { Do you think CH } \\
\text { designations affect } \\
\text { outcomes in other ways? }\end{array}$ & \multicolumn{2}{|c|}{$\begin{array}{l}\text { - } \quad \text { They focus attention on particularly important areas } \\
\text { - } \quad \text { They help the services develop a better understanding of habitat needs } \\
\text { - } \quad \text { They cause actors "to take the ESA a little more seriously" } \\
\text { - } \quad \text { They create the inaccurate impression that non-designated areas are unimportant } \\
\text { - "Critical habitat has proved to be useful in negotiating regional conservation } \\
\text { strategies for section } 10(\mathrm{a})(1)(\mathrm{B}) \text { permits" }\end{array}$} \\
\hline $\begin{array}{l}\text { Have you seen a change } \\
\text { over time in the ways in } \\
\text { which CH designations } \\
\text { affect implementation? }\end{array}$ & \multicolumn{2}{|c|}{$\begin{array}{ll}\text { - } & \text { Yes; it's an "evolving concept" } \\
\text { - } & \text { More internal scrutiny of adverse modification questions } \\
\text { - } & \text { Greater willingness to designate unoccupied habitat } \\
\text { - } & \text { Biologists are increasingly able to get project proponents to change projects; "it } \\
\text { didn't used to be that way." } \\
\text { - } \quad \text { No, it's still not that important in my region }\end{array}$} \\
\hline
\end{tabular}

${ }^{190}$ This table should be read with a few caveats in mind. First, I did not ask for specific yes/no/I don't know answers, and as a consequence the categories for the "by the numbers" column reflect the range of answers I received. Second, representative comments that do not appear in quotes are paraphrased. Third, one regional office provided me an email combining the responses of multiple biologists in several field offices, and I have treated that as a single response. In short, this is a sampling of views, not a formal survey. 


\section{Adverse modification in the courts}

Consultation processes occasionally culminate in litigation, and the courts therefore help determine the effect of the adverse modification prohibition. Judicial influence has been the focus of much of the previous legal literature on critical habitat, ${ }^{191}$ and from those analyses several hypotheses have emerged. Some commentators have argued that critical habitat designations are essentially inconsequential for judicial review, ${ }^{192}$ while others have suggested that they add teeth to judicial review of no-jeopardy opinions. ${ }^{193}$ Interestingly, most legal commentators agree that judicial review of the adverse modification prohibition has little significance except to the extent it bolsters the jeopardy review. ${ }^{194}$ To test these hypotheses, and to assess what effect judicial review might be creating, I also reviewed the body of caselaw addressing adverse modification.

The most striking quality of that body of caselaw is its small size. Academic and popular descriptions sometimes portray the consultation process as hopelessly embroiled in litigation, ${ }^{195}$ a characterization that tracks a broader view of the ESA. ${ }^{196}$ For decisions to list species and to designate critical habitat, that characterization has ample factual basis. ${ }^{197}$ But for the entire

${ }^{191}$ See, e.g., Houck, supra note 24, at 311 ("the ESA's prohibitions against jeopardy and habitat degradation are enforced solely through citizen actions in the courts").

${ }^{192}$ See, e.g., Robert J. Scarpello, Note: Statutory Redundancy: Why Congress Should Overhaul the Endangered Species Act to Exclude Critical Habitat Designation, 30 B.C. EnVTL. AfF. L. REV. 399,413 (2003).

${ }^{193}$ Salzman, supra note 25, at 323, 324-27; Houck, supra note 24, at 310 ("the ESA's prohibition on modification of critical habitat is interpreted by courts as strong and unyielding; the prohibition on jeopardy is viewed as discretionary and flexible. Moreover, the absence of designated critical habitat makes a case based on jeopardy highly problematical — if not insurmountable."); Josh Thompson, Comment: Critical Habitat Under the Endangered Species Act: Designation, Re-Designation, and Regulatory Duplication, 58 ALA. L. REV. 885, 890 (2007).

194 Salzman, supra note 25, at 324-27; Scarpello, supra note 192, at 413 ("there does not appear to be any case where a court found "adverse modification" of a critical habitat without also finding "jeopardy" to a listed species").

${ }^{195}$ See, e.g., Jamison Colburn, The Indignity of Federal Wildlife Habitat Law, 57 ALA. L. REV. 417, 443

(2005) (asserting that consultation occurs in the shadow of "the inevitable court challenge").

${ }^{196}$ See, e.g., David J. Hayes, A Lack of Leadership on all Sides, 21 ENVTL. F. 46, 46 (2004) (lamenting

"litigators - rather than dealmakers - dominating the ESA landscape of late.").

${ }^{197}$ See, e.g., Testimony of Craig Manson, Assistant Secretary for Fish and Wildlife and Parks, U.S. Department of the Interior, Before the House Committee on Resources, Regarding H.R. 3824, The Threatened 
thirty-eight year history of the ESA, Lexis and Westlaw combined contain only twenty decisions invoking the adverse modification prohibition to challenge federal agency actions. ${ }^{198}$ Not every litigated matter produces a judicial decision, and not all judicial decisions are published on Lexis or Westlaw. But with the 2005-2009 period producing over 4,000 biological opinions just for fish species, twenty judicial opinions for all species over the entire life of the statute seems a rather small number. ${ }^{199}$ The overwhelming majority of adverse modification decisions are not litigated, and the extent of judicial oversight over most consultation processes is surprisingly minimal.

The few decisions that do exist call into question the prior hypotheses about judicial review of adverse modification decisions. First, several commentators, observing that no court had ever set aside a no-adverse-modification determination without also setting aside a nojeopardy determination, asserted that the adverse modification inquiry had assumed no independent significance for judicial review. ${ }^{200}$ Those observations were generally accurate when written, but more recent cases undermine the claim. Courts have set aside no-adverse-

and Endangered Species Recovery Act of 2005, September 21, 2005 (describing the numbers of listing and designation cases).

${ }^{198}$ Tenn. Valley Auth. v. Hill, 437 U.S. 153 (1978); Butte Envtl. Council v. U.S. Army Corps of Engineers, 607 F.3d 570 ( $9^{\text {th }}$ Cir. 2010); Ctr. For Native Ecosystems v. Cables, 509 F.3d 1310 (10th Cir. 2010); Miccosukee Tribe v. U.S. Fish and Wildlife Serv., 566 F.3d 1257 (11th Cir. 2009); Nat'l Wildlife Federation v. Nat'l Marine Fisheries Serv., 524 F.3d 917 (9th Cir. 2008); Gifford Pinchot Task Force v. U.S. Fish and Wildlife Serv., 378 F.3d 1059 ( $9^{\text {th }}$ Cir. 2004); American Rivers v. NMFS, 1999 U.S. App. LEXIS 3860 ( $9^{\text {th }}$ Cir. 1999); National Wildlife Federation v. Coleman, 529 F.2d 359 ( $5^{\text {th }}$ Cir. 1976); Forest Serv. Emps. v. United States Forest Serv., 726 F. Supp. 2d 1195 (D. Mont. 2010); S. Yuba River Citizens League v. Nat'1 Marine Fisheries Serv., 723 F. Supp. 2d 1247 (E.D. Cal. 2010); Rock Creek Alliance v. Bradford, 2010 U.S. Dist. LEXIS 43880 (D. Mont. 2010); Pacific Coast Federation of Fishermen's Associations v. Gutierrez, 606 F.Supp.2d 1122 (E.D.Cal. 2008); Nez Perce Tribe v. NMFS, 2008 U.S. Dist. LEXIS 28107 (D. Id. 2008); NRDC v. Kempthorne, 506 F. Supp. 2d 322 (E.D. Ca. 2007); Oregon Natural Desert Ass'n v. Lohn, 485 F. Supp. 2d 1190 (D. Or. 2007); Ctr. For Biological Diversity v. BLM, 422 F. Supp. 2d 1115 (N.D. Cal. 2006); NRDC v. Rodgers, 381 F. Supp. 2d 1212 (E.D. Cal. 2005); National Wildlife Federation v. National Marine Fisheries Service, 235 F.Supp.2d 1143 (W.D.Wash., 2002); Idaho Rivers United v. NMFS, 1995 WL 877502 (W.D. Wash. 1995). I have also included Preserve Our Island v. Army Corps of Engineers, 2009 WL 2511953 (W.D.Wash. 2009), a case in which the plaintiffs successfully challenged a determination that consultation was unnecessary, in this group.

${ }^{199}$ For older data on numbers of consultations, see United STATES GENERAL ACCOUNTING OFFICE, ENDANGERED SPECIES ACT: TYPeS AND NuMBERS OF IMPLEMENTING ACTIONS 30 (1992).

${ }^{200}$ See supra note 192. 
modification determinations, finding both errors of law and conclusions unsupported by factual evidence, without also setting aside no-jeopardy determinations. ${ }^{201}$ Even when courts have rejected both no-adverse-modification and no-jeopardy determinations, or have upheld both, they have often — though not always - analyzed the two issues independently. ${ }^{202}$ And, interestingly, plaintiffs have done rather well, winning fifteen of the twenty adverse modification cases. The overall body of cases remains too small to support definitive conclusions about judicial approaches, but at the very least, the cases indicate that courts usually ascribe independent procedural and substantive significance to the ESA's adverse modification requirements.

Second, the judicial decisions provide little support for the assertion that critical habitat designations add stringency to judicial review of no-jeopardy determinations. The authors who developed this hypothesis did so by evaluating a few early consultation cases. ${ }^{203}$ They found that in cases involving designated critical habitat, no-jeopardy determinations were set aside, while in some others not involving critical habitat, those no-jeopardy determinations were upheld. Initially, those older cases provide thin support for the conclusion. In most of the cases where jeopardy determinations were set aside, the factual circumstances were remarkable, with agencies proposing actions that posed extraordinary threats to listed species' survival. ${ }^{204}$ Tennessee Valley Authority v. Hill, the seminal snail darter case, is a good example; the proposed dam was expected to obliterate the species, and the jeopardy prohibition clearly prohibits such an

${ }^{201}$ Gifford Pinchot Task Force v. U.S. Fish and Wildlife Serv., 378 F.3d 1059, 1069-70 (9th Cir. 2004) (rejecting the regulatory definition of adverse modification); Nez Perce Tribe v. NMFS, 2008 U.S. Dist. LEXIS 28107 (D. Id. 2008); National Wildlife Federation v. National Marine Fisheries Service, 235 F.Supp.2d 1143, 115961 (W.D.Wash. 2002); Idaho Rivers United v. NMFS, 1995 WL 877502, *4-*8 (W.D. Wash. 1995).

${ }^{202}$ E.g. Nat'l Wildlife Federation v. Nat'l Marine Fisheries Serv., 524 F.3d 917, 929-31 (jeopardy), 933-36 (adverse modification); but see American Rivers v. NMFS, 1999 U.S. App. LEXIS 3860,*4**9 ( ${ }^{\text {th }}$ Cir. 1999) (holding that the adverse modification analysis was appropriately subsumed within the jeopardy analysis).

${ }^{203}$ See Salzman, supra note 25, at 324-27; Houck, supra note 24, at 307-09.

${ }^{204}$ See TVA v. Hill, 437 U.S. at 171; Coleman, 529 F.2d at 362-68 (describing FWS's repeated efforts to assert that the proposed project posed a major threat to a listed species). 
action even absent a critical habitat designation. ${ }^{205}$ Those compelling fact patterns, rather than some subliminal effect of a critical habitat designation, provide a simpler explanation for the results. ${ }^{206}$ Moreover, at least in the set of decisions available on Lexis or Westlaw, no court has ever actually stated that a critical habitat designation changed the outcome of its jeopardy analysis. ${ }^{207}$ If the designations did so matter, one would expect a court to say so.

The cases therefore demonstrate that critical habitat can hold independent significance for judicial review, and does not just stiffen the jeopardy review. But the courts hold mixed views on how much critical habitat matters, particularly when incremental habitat degradation is at issue. In several decisions, courts have questioned the services' willingness to allow incremental habitat degradation, often criticizing the agencies' failure to acknowledge the relationship between incremental degradation and cumulative harm. ${ }^{208}$ But in several other decisions, courts have allowed no-adverse-modification determinations to stand even where the projects were expected to degrade habitat. ${ }^{209}$

${ }^{205} 437$ U.S. 153, 171 (1978) ("We begin with the premise that operation of the Tellico Dam will either eradicate the known population of snail darters or destroy their critical habitat.").

${ }^{206}$ One can also readily find cases in which jeopardy findings were set aside without any discussion of critical habitat. See, e.g., Pac. Coast Fed. of Fisherman's Assoc. v. NMFS, 265 F.3d 1028 (9th Cir. 2001).

${ }^{207}$ The closest case is Froehlke, in which the court stated: "It is significant that the Secretary of the Interior has the power... designate a critical habitat for an endangered species immediately... No such power has been invoked with regard to the Indiana bat and the Meramec Lake Park Project." 534 F.2d at 1301 n.37. But earlier in the same footnote, the court remarked that "even if these caves were presently designated 'critical habitat,' we could not say that trial court determination, namely that $\mathrm{s} 7$ is not being violated, is clearly erroneous." Id.

${ }^{208}$ See Nat'1 Wildlife Federation v. Nat'l Marine Fisheries Serv., 524 F.3d 917 (9th Cir. 2008); Oregon Natural Desert Ass'n v. Lohn, 485 F.Supp.2d 1190, 1198-1202 (D.Or. 2007); Nez Perce Tribe v. NMFS, 2008 WL 938430, *10 (D.Idaho 2008) ("This wide-spread degradation of habitat means, according to NOAA, that "each additional increment of habitat loss' could result in an exponential increase in the extinction risk.... Given these findings, the Court cannot conclude that the action area is too small to matter.).

${ }^{209}$ Butte Envtl. Council v. U.S. Army Corps of Engineers, 607 F.3d 570, 578-79 (9th Cir. 2010); Miccosukee Tribe of Indians of Fla. v. U.S., 566 F.3d 1257, 1269-1271, (11th Cir. 2009) (upholding a biological opinion for a project that undisputedly would cause short-term harm to species habitat); Rock Creek Alliance v. U.S. Forest Service, --- F.Supp.2d ----, 2010 WL 1872864. *40-*41 (D.Mont. 2010) (upholding a no-adversemodification determination despite uncontested evidence that critical habitat would be slightly degraded). 
No case better illustrates this latter approach than the Ninth Circuit's recent decision in Butte Environmental Council v. U.S. Army Corps of Engineers. ${ }^{210}$ There, the court considered a challenge to a proposed development project that would allow the filling of wetlands designated as critical habitat. ${ }^{211}$ A significant area surrounding the wetlands also was designated as critical habitat, and the project would impact that area is well. ${ }^{212}$ In total, according to FWS, "the proposed development would destroy 234.5 acres of... critical habitat" of two endangered animal species. ${ }^{213}$ A listed plant species also was present, and 242.2 acres of its habitat "would be destroyed." 214 The court emphasized that these areas represented less than one percent of the total designated critical habitat of each species, but, as it also acknowledged, "the proposed project would contribute to a local and range-wide trend of habitat loss and degradation."215 The FWS nevertheless issued no-adverse-modification and no-jeopardy determinations, and the lawsuit ensued. As the Ninth Circuit's opinion makes clear, no question existed that the project would destroy hundreds of acres of critical habitat, and no one could dispute that the ESA expressly forbids federal agencies from approving actions likely to "destroy or adversely modify" critical habitat. ${ }^{216}$ But the court allowed the action to proceed. ${ }^{217}$ "The FWS's determination" the court concluded, "that critical habitat would be destroyed was thus not inconsistent with its finding of no 'adverse modification.' After all, the project would affect only a very small percentage of the total critical habitat." ${ }^{218}$

D. Summarizing critical habitat's role

${ }^{210} 607$ F.3d 570 .

${ }^{211} I d$. at $578-79$.

${ }^{212} I d$.

${ }^{213} I d$. at 578 . The project proponent planned to offset a small percentage of these impacts through restoration or protection of similar habitat elsewhere. Id. at 579.

${ }^{214} I d$. at 579 .

${ }^{215} I d$. (quoting FWS's biological opinion).

${ }^{216} 16$ U.S.C. § 1536(a)(2) (2006).

${ }^{217} 607$ F.3d at 583.

${ }^{218}$ Id. 
The foregoing discussion suggests that critical habitat designations have little effect upon consultation processes and only modest effects upon judicial review. The effects are not nonexistent; the adverse modification prohibition has affected the outcome of several cases, even if a gap exists between the requirements articulated by the statute and those enforced by the courts. Agency biologists involved in consultation processes thought that critical habitat designations affect negotiations between the services and action agencies. But the effects of critical habitat designations upon the regulators and upon judicial review still have been minor.

That does not mean that critical habitat is unimportant. Even if designations result in little additional regulatory constraint, they send signals to action agencies and to private entities. Unlike the listing of a species, which signals the possibility of ESA-related regulatory constraints only if one knows where the species is likely to live, lines on a map are easy to understand, and designations therefore can help landowners and action agencies avoid conflict with species needs. ${ }^{219}$ Even if critical habitat does not substantially change the services' regulatory approaches, regulated entities seem to believe that designations do increase regulatory stringency, and that belief may also deter some activities that might otherwise harm species. ${ }^{220}$ And designations may affect the regulatory approaches of other environmental agencies by providing a signal that some habitats are particularly important. ${ }^{221}$ The signals are not uniformly beneficial to species. The agencies have complained that when designations are finalized, nondesignated habitat actually becomes harder to protect, ${ }^{222}$ and one study has suggested that

${ }^{219}$ See FWS biologist interview, January 26, 2011 (observing that action agencies will sometimes try to avoid projects in critical habitat areas). They also can inflame conflict. See Salzman, supra note 25, at 336 (quoting a former FWS official: "As soon as you draw a line on the map, they see it as the first step toward the feds condemning the land.").

${ }^{220}$ See supra Table 3.

${ }^{221}$ See, e.g., California State Water Resources Control Board, Order No. WR 2000-13 (October 19, 2000), at 60-62 (referring to a critical habitat designation when determining the appropriate extent of fish protection).

${ }^{222}$ FWS biologist telephone interview, December 7, 2010. 
proposed designations can spur preemptive conversion of habitat. ${ }^{223}$ The extent of these effects also is far from certain and is a worthy subject for additional research. But most of the biologists I interviewed agreed that providing a warning about the presence of listed species does promote those species' protection.

In addition, the process of designating critical habitat can provide information that helps the services implement other statutory requirements. That process currently includes an effort to identify some of the species' key habitat needs. ${ }^{224}$ While some of that information already may be available to agency staff-the agencies routinely consider habitat threats in listing decisions and jeopardy analyses - several biologists told me that the critical habitat designation process leads to a more thorough and rigorous analysis of habitat needs. ${ }^{225}$ The resulting information then can help the agencies as they engage in consultations, develop recovery plans, negotiate habitat conservation plans, and target spending to conservation and recovery projects. ${ }^{226}$

In short, critical habitat does matter. But critical habitat has not yet mattered in quite the ways or to quite the extent that the statutory language would lead one to expect. That could change, of course, and several biologists thought that regulatory protection of critical habitat would evolve. But to date, any perception of substantially increased regulatory protection for species, or of heightened regulatory burdens for regulated entities, is mostly a mirage.

\section{Habitat Protection And the Narratives of the ESA}

${ }^{223}$ See John A. List, Michael Margolis \& Daniel E. Osgood, Is the Endangered Species Act Endangering Species? 1-2 (Nat'1 Bureau of Econ. Research, Working Paper No. 12777, 2006), available at http:// www.nber.org/papers/w12777.

${ }^{224}$ See, e.g., Endangered and Threatened Wildlife and Plants; Designation of Critical Habitat for the Polar Bear (Ursus maritimus) in the United States, 75 Fed. Reg. 76086, 76115 (Dec. 7, 2010) (identifying the "primary constituent elements" of polar bear habitat).

${ }^{225}$ E.g. FWS Biologist telephone interview, November 4, 2010.

${ }^{226} I d$. 
So far, this Article may read like an attempt to document a scandal. A core axiom of our administrative law system—indeed, our legal system — is that agencies should implement the law as it is written. ${ }^{227}$ Administrative policy disagreements with legal requirements are no basis for non-implementation, at least in the view of most scholars and judges, ${ }^{228}$ for we are, we tell ourselves, a nation run by "a government of laws, not of men."229 With critical habitat, that faithful implementation has not happened. The services have provided substitute protections, but to many commentators, the mitigation measures and conditions will seem rather unimpressivethe sops thrown out by an administrative law system "geared," as one scholar recently put it, "almost entirely to the legalization of natural resource damage."230 Other readers may be tempted to draw a rather different conclusion. They may see the agencies' efforts as attemptspartial and perhaps futile - to inject some restraint into a crazy law that, if faithfully implemented, would impose remarkably rigid constraints across much of the American landscape. ${ }^{231}$

These conclusions would lead in almost entirely opposite directions, except for one shared conviction: in both narratives, the existing system of endangered species protection is deeply flawed and requires fundamental reforms. Yet this Part argues that both narratives are at best incomplete. There are significant problems with existing regulatory approaches, and Part VI explains how those problems might be addressed. But there is also much to commend in those existing approaches. This section therefore explains why, despite what may initially seem like

${ }^{227}$ See David S. Tatel, The Administrative Process and the Rule of Law, 34 HARV. L. REV. 1, 2 (2010).

${ }^{228}$ See North Carolina v. EPA, 531 F.3d 896, 910 (D.C. Cir. 2008) ("All the policy reasons in the world cannot justify reading a substantive provision out of a statute."). For a contrary view, see Antonin Scalia, The Doctrine of Standing as an Essential Element of the Separation of Powers, 17 SUFFOLK U. L. REV. 881, 897 (1983) ("The ability to lose or misdirect laws can be said to be one of the prime engines of social change.").

${ }^{229}$ Youngstown Sheet \& Tube Co. v. Sawyer, 343 U.S. 579, 646 (1952) (Jackson, J. concurring).

${ }^{230}$ Wood, supra note 48 , at 55.

${ }^{231}$ See generally Charles C. MANn AND Mark L. Plummer, NoAh's Choice: The Future of ENDANGERED SPECIES (1995). 
empirical evidence of agency malfeasance, this study provides little support for some of the prevalent cynicism about ESA implementation and, more generally, about environmental and administrative law, and why the reforms I propose involve selective tinkering rather than a comprehensive overhaul.

\section{A. The persistence of flexibility}

At a press conference in 2008, then-Secretary of Interior Dirk Kempthorne referred to the Endangered Species Act as "perhaps the least flexible law Congress has ever enacted."232 This was not a new claim. For years, the ESA's many political and academic critics have argued that it creates an unreasonably rigid regulatory scheme. ${ }^{233}$ Many critics contrast that flawed rigidity with administrative reforms or alternative regulatory approaches designed to introduce more creativity, negotiation, flexibility, and decentralization to the regulatory process. ${ }^{234}$ All of those critiques track some of the broader narratives of environmental law. Both political and academic critics often assert that traditional regulatory approaches are too top-down, rigid, and insensitive to local conditions, that they are ultimately antithetical to the sort of innovation an effective legal regime should promote, and that they should be dramatically reformed. ${ }^{235}$

\footnotetext{
${ }^{232}$ Remarks by Secretary Kempthorne, Press Conference on Polar Bear Listing (May 14, 2008), at http:/www.fws.gov/home/feature/2008/polarbear012308/pdf/press-conference-remarks.pdf.

233 See, e.g., MANN AND PLUMMER, supra note 231, at 212-24 (characterizing the statute as fatally flawed because of its inflexibility); William F. Pedersen, Using Federal Environmental Regulations to Bargain for Private Land Use Control, 21 YALE J. ON REG. 1, 3-4 (2004) (criticizing the statute as a case study in "command and control" regulation); M. Reed Hopper, Too Much Power for Too Little Results, 21 ENVTL. F. 47, 47 (2004) ("First, under the act the federal government asserts virtually absolute power over land and water use. Second, the act does not balance the cost of species protection with the impacts on humans.”); Andrew P. Morriss and Richard L. Stroup, Quartering Species: The “Living Constitution," the Third Amendment, and the Endangered Species Act, 30 ENVTL. L. 769, 785-86, 788-90 (2001) ("the ESA was designed around a command-and-control model.").

${ }^{234}$ E.g., MANN AND PLUMMER, supra note 231, at 219 (arguing for different approaches in different regions), 224-33 (arguing that the ESA's regulatory provisions should not automatically be invoked following a listing and that a habitat purchases should be emphasized as an alternative to regulatory prohibitions); Pedersen, supra note 233, at 3-4. Thompson, supra note 30, at 321 ("Virtually all interested parties agree that the ESA can be significantly improved, despite their vocal disagreement as to how this should be achieved.").

${ }^{235}$ See, e.g., Carol A. Casazza Herman et al., Breaking the Logjam: Environmental Reform for the New Congress and Administration, 17 N.Y.U. ENVTL. L.J. 1, 1 (2008) (asserting that the United States is "burdened with obsolescent statutes and regulatory strategies"); Stewart, supra note 39, at 203, 213.
} 
The claim that the ESA is rigidly implemented is impossible to reconcile with the agencies' actual track record. Every study to consider the section 7 process has found that jeopardy and adverse modifications are rare, and that even when the services do find jeopardy or adverse modification, projects still generally proceed. ${ }^{236}$ My study confirms those prior results, and adds two additional findings. First, even when projects are clearly expected to degrade critical habitat and to take listed species, jeopardy and adverse modification determinations are still very infrequent. ${ }^{237}$ Moreover, that rarity has persisted despite a series of cases successfully challenging regulations authorizing permissive approaches. ${ }^{238}$ Second, for some classes of actions with major habitat impacts, formal consultation happens hardly at all. ${ }^{239}$

The ESA does still impose procedural and substantive constraints on many individual projects, but the nature of those constraints undermines some of the classic critiques of the ESA. Those conventional critiques often assert that the ESA, and federal environmental law generally, are insensitive to local conditions. ${ }^{240}$ But actual biological opinions reveal that both FWS and NMFS usually try to craft location-specific protective measures. ${ }^{241}$ Rather than evolving through the top-down edicts of insulated bureaucrats in Washington, those measures originate at regional or field offices, usually through ongoing negotiations with regulated entities. ${ }^{242}$ More

${ }^{236}$ See supra note 148 .

237 See infra Table 2.

${ }^{238}$ See supra note 113 and accompanying text.

${ }^{239}$ See supra notes 167-169 and accompanying text.

${ }^{240}$ E.g. Jonathan Remy Nash, Trading Species: A New Direction for Habitat Trading Programs, 32 COLUM. J. ENVTL. L. 1, 7 (2007) ("the Act adopts the clumsy and inefficient centralized command-and-control mechanism."); Herman et al., supra note 235, at 3 (criticizing federal environmental law's allegedly heavy reliance "on top-down, hierarchical regulatory approaches" and arguing that states can be "more nimble" in developing localized responses).

${ }^{241}$ See supra notes 178-182 and accompanying text.

${ }^{242}$ See supra Table 3; Amy Sinden, The Importance of Absolutes: Combating the Politics of Power in Environmental Law, 90 IOWA L. REV. 1405, 1494 ("Ultimately, the ESA's absolute standards involve a negotiation between environmental and economic interests...”). 
generalized standards do evolve, ${ }^{243}$ but again the process is often bottom-up and negotiationdriven, with field or regional office biologists working with frequently regulated agencies to develop standards for particular classes of projects. ${ }^{244}$

This process is not cost-free, of course. ${ }^{245}$ Consultation takes time, and project conditions require money to implement. But the scheme is implemented in cost-sensitive ways. First, the constant use of negotiations provides opportunities to identify mitigation measures with relatively low financial cost and relatively high environmental returns. Second, the selective but frequent use of generic standards suggests that action agencies and the services are sensitive to the tradeoff between more broadly-applicable standards, which can provide greater predictability for project designers and can expedite the consultation process, and site specific conditions, which can provide more carefully tailored protection, and are attempting to manage that tradeoff in a manner that balances cost-reduction and environmental protection. ${ }^{246}$

The process also offers some opportunities for learning, adaptation, and regulatory evolution. Because the services repeatedly interact with the same agencies, ${ }^{247}$ and because they routinely require monitoring of the implementation of their projects and of direct takes of species, they have created mechanisms for feedback. ${ }^{248}$ These mechanisms are far from perfect. Biological opinions rarely require contributions to species population or distribution monitoring,

\footnotetext{
${ }^{243}$ See NMFS Biologist Interview, Nov. 16, 2010 (explaining that the services increasingly rely on standardized conditions, partly because they lower administrative costs and partly because action agencies are willing to accept more protective conditions as a tradeoff for regulatory certainty).

${ }^{244}$ See NMFS Biologist Interview, November 16, 2010.

245 See, e.g., General ACCOUnTING OfFICE, ENDANGERED SPECIES: More Federal MANAGEMENT Attention Is NeEded to Improve the Consultation Process 4-5, 54-56 (2004) (describing substantially increased permitting costs that applicants attributed to species listings).

${ }^{246}$ See NMFS Biologist Interview, November 16, 2010 (describing standardized conditions as an important way to expedite consultations and reduce administrative costs).

${ }^{247}$ A few agencies - the Army Corps of Engineers, Bureau of Reclamation, Forest Service, and Bureau of Land Management-account for the vast majority of the consultations I reviewed.

${ }^{248}$ Almost every opinion I reviewed required some form of monitoring. Usually the action agency was required to monitor direct take of the species and to monitor and document its implementation of conservation measures and RPMs. See also CONSULTATION HANDBOOK, supra note 72, at 9-1 to 9-2 (describing monitoring requirements).
} 
even though such monitoring which might provide important data for developing broader conservation and protection strategies. ${ }^{249}$ The agencies also never have followed through on a proposal laid out in their consultation handbook, which calls for the creation of a centralized database of monitoring results. ${ }^{250}$ Agency biologists told me that the actual extent of compliance monitoring is uneven. ${ }^{251}$ But the agencies are gathering some data and are creating some opportunities for dialogue and learning, and that is an important start. Agency staff thought that dialogue and learning was paying dividends; in interviews, several biologists explained ways that their approaches to mitigation were evolving and improving over time. ${ }^{252}$

In short, ESA implementation already involves many of the approaches that would-be reformers suggest are necessary to an effective regulatory scheme, and it involves those elements despite the persistence of an old-style regulatory structure. To someone who argues that the ESA's basic goals are not worthwhile, that may be small consolation, but many of the critiques of the ESA focus on means rather than ends, and the means are more sensible than many of the critics acknowledge. ${ }^{253}$ There is enough room for creativity and flexibility within existing approaches to accommodate many of the flexibility-oriented reformers' stated goals.

B. The absence of capture ${ }^{254}$

\footnotetext{
${ }^{249}$ On the importance of such monitoring, see Eric Biber, Environmental Law's Monitoring Problem (forthcoming __).

${ }^{250}$ See CONSUlTATION HANDBOOK, supra note 72 , at 9-2 to 9-6 (describing this program). I found no evidence of its existence.

${ }^{251}$ E.g. FWS Biologist Interview, November 17, 2010 (stating that the services have little capacity to do follow-up work).

${ }^{252}$ NMFS Biologist Interview, November 16, 2010 (describing the evolution of negotiated standardized conditions); NMFS Biologist Interview, November 22, 2010 (describing increased interest in off-site mitigation).

${ }^{253}$ Many critiques of the ESA argue that the core problem with the act is not that its goals are not worthwhile but instead that its means create perverse incentives. See, e.g., Angela Logomasini and Robert J. Smith, Protect Endangered Species, in From Liberate to STIMUlate: A BiPARTISAN AgENDA TO RESTORE Limited GOVERnMENT AND REVIVE AMERICA'S ECONOMY 62, 62 (Ivan Osorio and Wayne Crews eds. 2011) ("The Endangered Species Act (ESA) of 1973 is bad for wildlife, because it is bad for people.").

${ }^{254}$ A "captured" agency has become controlled by the entities it is supposed to be regulating. See Thomas W. Merrill, Capture Theory and the Courts, 1967-83, 72 CHI.-KENT L. REV. 1039, 1043 (1997).
} 
This Article is by no means the first to challenge the common view that the ESA is a rigidly-implemented statute, or that environmental law generally is inflexibly implemented by bureaucratic zealots. For decades, some commentators have argued that the ESA actually is quite pliable - excessively so, some say -in practice. ${ }^{255}$ Perhaps the most eloquent advocate of this view is Oliver Houck, who once argued that "[a] handful of piers for powerboats in designated critical habitat areas aside, there is no evidence that formal consultation under the Endangered Species Act is stopping the world. Indeed, there is little evidence that it is changing it very much at all."256 In Houck's widely-shared view, the implementing agencies have responded to intense political pressure by reading rigid mandates out of the statute and interpreting it as largely discretionary. ${ }^{257}$ They then have invoked that discretion to avoid imposing meaningful regulatory control. ${ }^{258}$ Some of these critics are more sanguine about the ESA's protective force, but they still argue that it protects listed species only because the facial rigidity of its mandates means that even a watered-down version of the ESA still holds substantial force. ${ }^{259}$ In short, while the unsympathetic critics view the ESA as the poster child

${ }^{255}$ See, e.g., Sinden, supra note 242, at 1491-1510; Houck, supra note 24, at 279; Ray Vaughan, State of Extinction: The Case of the Alabama Sturgeon and the Ways Opponents of the Endangered Species Act Thwart Protection of Rare Species, 46 ALA. L. REV. 569, 596-97 (1995) ("virtually all of the work of the FWS under the ESA seems to favor industry").

The ESA literature also contains many views between these poles. E.g. STEVEN LEWIS YAFFEE, Prohibitive Policy: IMPLEMENTING THE FEDERAL ENDANGERED SPECIES ACT (1982) (observing that facially prohibitive policies are actually implemented with flexibility); J.B. Ruhl, Is the Endangered Spcies Act EcoPragmatic?, 87 MINN. L. REV. 885, 886 (2003) (arguing that the ESA is sometimes a "pit bull" but also "has accommodated well-planned land development around the nation with a measure of flexibility not characteristic of many other environmental laws"); Bradley C. Karkkainen, Biodiversity and Land, 83 CORNELL L. REV. 1, 21-22 (1997).

${ }^{256}$ Houck, supra note 24 , at 321.

${ }^{257}$ Id. at 279 ("[T] he Departments of Interior and Commerce ... have converted an act of specific stages and clear commands into an act of discretion."); see Holly Doremus, Adaptive Management, The Endangered Species Act, and the Institutional Challenges of "New Age” Environmental Protection, 41 WASHBURN L.J. 50,62 (2001) (describing "[t]he tendency to use discretion to reduce the protection of biological resources under political pressure").

${ }^{258}$ See id. ([T]he ESA has accommodated the overwhelming majority of human activity without impediment."); Vaughan, supra note 255, at 596-97.

${ }^{259}$ See Sinden, supra note 242, at 1498. 
for regulatory rigidity run amok, many sympathetic critics view it as a classic study in regulatory accommodation and capture.

The evidence that this dynamic sometimes exists is overwhelming, ${ }^{260}$ and this study provides some new support for this view. Most importantly, a central conclusion of this study is that the adverse modification prohibition has barely been implemented, and that the services have eschewed faithful application of the statute in favor of a more discretionary approach that often allows projects to degrade designated critical habitat. ${ }^{261}$ The capture-and-accommodation hypothesis provides a plausible explanation for that choice. Similarly, both individual biological opinions and individual court cases demonstrate that the agencies sometimes adopt strained reasoning in support of no-adverse-modification decisions, sometimes in response to acknowledged political pressure. ${ }^{262}$ That strained reasoning suggests a vigorous effort to avoid imposing regulatory constraints. Though these machinations may sometimes seem remarkable, the motivation behind them is not hard to understand. No one could credibly dispute that the political pressures against species protection are persistent and intense.

But much of the evidence produced by this study does not comport with assertions that the services are captured agencies. Most importantly, that evidence indicates that the services are using the ESA to change thousands of proposed projects. Even as they have allowed the critical habitat protections to languish, they have consistently been finding that proposed projects will "take" species and have been imposing "reasonable and prudent measures," many of which

\footnotetext{
${ }^{260}$ See, e.g., Holly Doremus, Scientific and Political Integrity in Environmental Policy, 86 TEX. L. REV. 1601, 1603-1609 (2008) (describing several recent controversies).

${ }^{261}$ See supra part IV.

${ }^{262}$ See supra notes 164-166 and accompanying text; Natural Resources Defense Council v. Rodgers, 381 F.Supp.2d 1212, 1220 (E.D.Cal., 2005) (quoting agency emails about a politically-driven no-jeopardy opinion); Seattle Audubon Soc'y v. Evans, 771 F. Supp. 1081, 1089 (W.D. Wash.), aff'd, 952 F.2d 297 (9th Cir. 1991) (documenting heavy political pressure to adopt marginally protective approaches)..
} 
appear extensive and meaningful, upon almost all of the projects they review. ${ }^{263}$ Though those "reasonable and prudent measures" are sometimes minimal or hortatory, the services have multiple other ways, all frequently used, to minimizing projects' adverse effects, and often to change projects so that they provide net benefits for species' habitat. ${ }^{264}$ Compared to a baseline of complete ESA implementation, the results may seem disappointing, but they still represent much more environmental protection than the services would ever accomplish if they really were acting only in response to litigation — which, as discussed above, is relatively rare.

The time involved in consultation processes also provides an indication that the agencies are not pushover regulators. Though biologists told me ways they had tried to expedite the consultation process, none suggested that they were doing so at the expense of species protection, and particularly for complex projects, the consultation process can last months or even years. $^{265}$ Nor did any of the biologists I spoke with fit the model of a captured bureaucrat. Instead, I heard consistent commitment to the underlying statutory goal of species protection, and consistent description of the ways biologists tried to fulfill that commitment. The biologists believe, as one put it, that under section 7 they "have a lot of flexibility to do things that are good for species, ${ }^{, 266}$ and that they are actively putting that flexibility to use. They were aware, of course, of the political controversies associated with the ESA, and some acknowledged ways in which those pressures affected their work. ${ }^{267}$ Some also expressed frustration with what they perceived as a failure to develop the concept of adverse modification or to use it to its full

${ }^{263}$ See supra Table 2.

264 This finding also contravenes the commonly-asserted view that the agencies rarely regulate under section 9. See, e.g., Vaughan, supra note 255 at 597 ("the prohibitions against takings in section 9 are not enforced with anything resembling vigor"); Thompson, supra note 30, at 315.

265 See GAO, supra note 148 , at 3-5.

${ }^{266}$ FWS biologist telephone interview, December 21, 2010.

${ }^{267}$ E.g. FWS biologists interview, November 3, 2010 (acknowledging that section 7 implementation is politically sensitive). 
potential. $^{268}$ They were similarly aware of the influence of litigation upon implementation; in fact, several mentioned that Gifford Pinchot Task Force and related cases had compelled (or empowered) the services to rethink their approach to critical habitat. ${ }^{269}$ But both interviews and documentary evidence demonstrate that a public choice-based theory of administrative governance, in which the services simply respond to the balance of power created by development interests' lobbying and environmental groups' lawsuits, misses a key part of the story. Instead, a meaningful regulatory effort comes from within the agencies.

The core point of this discussion is not that the existing approaches to habitat protection are wonderful and in no need of change. A regulatory approach that diverges from statutory requirements obviously is problematic, particularly if the divergence threatens to undermine achievement of the basic statutory goal of removing species from the list. That potential divergence is not just harmful to species; for potentially regulated entities, recovery means a respite from some of the regulatory stringency of the ESA, and therefore ought to bring significant economic benefits. But even with those caveats, the services' efforts support an unconventionally positive view of at least part ${ }^{270}$ of the existing regulatory scheme. That regulatory scheme already has given those agencies useful tools to work with, and the agencies have used those tools in creative, pragmatic, and, often, effective ways. With modest reforms-

\footnotetext{
${ }^{268}$ E.g. FWS biologist interview, January 26, 2011 (explaining a common perception that biologists were "just documenting the demise until there's nothing left... [we] probably need a higher-level discussion on doing these analyses").

${ }^{269}$ See, e.g., NMFS biologist interview, November 22, 2010 (stating that Gifford Pinchot Task Force gave her more leverage to push for conditions that promoted recovery).

${ }^{270} \mathrm{I}$ am not arguing that this moderately rosy view of administrative agency practice should extend to the processes of listing species or of designating critical habitat. In both processes, little happens without litigation. But a decision to include something - whether that something is a species, habitat area, or chemical —in a regulatory system may involve very different dynamics than decisions about how to go about regulating the thing once the obligation to regulate is clear. The former type of decision often depends upon a push from litigation or legislation. See, e.g., Massachusetts v. EPA, 549 U.S. 497 (2007) (responding to EPA's reluctance to expand its regulatory program to encompass greenhouse gas emissions); DANIEL A. FARBER ET AL., ENVIRONMENTAL LAW AND POLICY $542,752-53$ ( $8^{\text {th }}$ ed. 2010) (describing EPA's reluctance to list hazardous air and water pollutants); Owen, supra note 129, at _ (describing EPA's reluctance to include stormwater sources in its regulatory program until compelled by litigation). The latter sometimes does not.
} 
none of them actually requiring legislative changes - providing more effective tools, the services could do even better.

\section{CRitical Habitat And the Challenges of InCRemental Degradation}

The preceding discussion indicates that the services are using the ESA to provide substantial habitat protection. Yet, paradoxically, a gap persists between the statutory mandate and actual agency practice. This section considers why that gap exists, how reforms might address it, and what the gap and its potential fixes reveal about the challenges of regulating small environmental harms.

A. The dilemma and the critical habitat response

Any effort to regulate incremental environmental degradation must address a crucial question: when are harms too small to trigger regulation? ${ }^{271}$ Yet neither the ESA itself, which suggests a stringent and prohibitory regulatory system, nor the services, which have taken a more permissive course, have developed an effective response.

This dilemma is difficult to resolve partly because each of the obvious answers is flawed. One possibility is to try to prohibit every contribution to the environmental problem, no matter how small. But in practice, the administrative costs of such an approach could be extraordinary, the burdens imposed might outweigh any environmental gain, and both the regulators and the regulated would likely resist implementation. ${ }^{272}$ Alternatively, regulators might prohibit only those actions that cause major harm (or prohibit nothing at all). But if the environmental problem is primarily caused by small actors, a regulatory approach focusing only on a few major

${ }^{271}$ See, e.g., Madeline June Kass, The NEPA Climate Paradox: Taking Greenhouse Gases into Account in Threshold Significance Determinations, 42 IND. L. REV. 47 (2009) (analyzing similar questions that arise in NEPA compliance).

${ }^{272}$ See id. at 71. 
actors will solve little. ${ }^{273}$ Moreover, any system that distinguishes between regulated "large" contributors and unregulated "small" ones faces a line-drawing problem. Environmental harms often exist on a continuum of scales, and if there is no clear distinction between small and large harms, any line will seem somewhat arbitrary. ${ }^{274}$ The distinction is even harder to draw if, as is often the case, no one knows how much harm each action will cause. ${ }^{275}$

This problem has been the Achilles heel of critical habitat protection. The statute itself suggests a very low regulatory threshold, under which the services would prohibit any federallyapproved worsening of critical habitat, no matter how minor. ${ }^{276}$ But without some creative additional measures, such an approach cannot work. The services already are politically embattled and administratively swamped-"barely keeping our heads above water," as one biologist put it - and it is difficult to imagine them performing individualized consultations on, let alone vetoing, many additional projects. ${ }^{277}$ Congress, which has preferred using its power of the purse to undercut ESA implementation, is unlikely to appropriate the funds necessary to support a larger workload. $^{278}$ The political backlash against more extensive regulatory prohibitions also would almost certainly be intense. Unsurprisingly, the services have not embraced this approach, and they have sometimes assured the world that they never will. ${ }^{279}$ Instead, they have chosen to prohibit a few major habitat modifications, to allow more minor modifications to proceed subject to conditions, to let other modifications proceed without any

\footnotetext{
${ }^{273}$ See Michael P. Vandenbergh, From Smokestack to SUV: The Individual as Regulated Entity in the New Era of Environmental Law, 57 VAND. L. REV. 515, 533-34 (2004).

${ }^{274}$ See generally Malcolm L. Hunter et al., Thresholds and the Mismatch Between Environmental Laws and Ecosystems, 23 CONSERVATION BIOLOGY 1053 (2009).

${ }^{275}$ See, e.g., supra notes 126-128 and accompanying text (discussing the impossibility of linking greenhouse gas emissions from specific activities to specific increments of habitat change).

${ }^{276}$ See supra notes 98-105 and accompanying text.

${ }^{277}$ FWS biologists interview, November 3, 2010.

${ }^{278}$ See Doremus, supra note 260, at 64 (describing Congressional efforts to hamstring ESA implementation).

${ }^{279}$ See Industrial ECONOMICS, INC. AND NORTHERN ECONOMICS, supra note 4, at ES-6 (stating that FWS will not use the polar bear critical habitat designation as a basis for regulating climate change).
} 
regulation at all, and to use a case-by-case approach to drawing the lines. That approach has several positive features - in practice, it functions rather similarly to the sort of feasibility-based performance standards that air and water quality regulators have successfully relied upon ${ }^{280}$ and it limits regulatory overreach, but it substitutes other problems.

First, the services' chosen approach necessitates distinguishing among levels of harm, and the services have struggled to define, let alone justify, the lines. Their regulations and guidance use fuzzy terms that simply suggest that thresholds might exist. ${ }^{281}$ The services now disclaim reliance on even those vague regulations and have not put forth any sort of generalized standard in their place. ${ }^{282}$ Nor have the courts set forth any sort of standard. ${ }^{283}$ As a practical matter, individual field offices and individual courts have been left to find thresholds on an ad hoc basis. Their choices have often been permissive, and their justifications sometimes seem premised on the dubious assumption that small harms pose no real threat to species. ${ }^{284}$

The services' chosen approach also may be insufficiently protective. Recovering species is a core goal of the ESA, and for good reason; if a species recovers, the environmental goals of the statute are served and regulated entities should face reduced regulatory burdens, for they will no longer be subject to the ESA's procedural and substantive constraints. But if a species was listed primarily because of the threat of habitat degradation — and, with most species, that was a primary, if not the primary, threat ${ }^{285}$-then allowing additional habitat degradation is fundamentally inconsistent with that goal. With some species, the harmful projects may not be creating an overall negative trend, for the services consistently impose protective conditions,

${ }^{280}$ See generally Oliver A. Houck, Of Bats, Birds and B-A-T: The Convergent Evolution of Environmental Law, 63 Miss. L.J. 403, 410-28 (1994) (explaining, and praising, feasibility-based standards); Wendy E. Wagner, The Triumph of Technology-Based Standards, 2000 U. ILL. L. REV. 83 (same).

${ }^{281}$ See supra notes 109-115 and accompanying text.

${ }^{282}$ See Jones Memorandum, supra note 114; Hogarth Memorandum, supra note 115.

${ }^{283}$ See supra notes 201-218 and accompanying text.

${ }_{285}^{284}$ See supra notes $164-166$ and accompanying text.

${ }^{285}$ See Wilcove et al., supra note 52. 
some sufficiently protective to avoid any negative habitat impact, and the public funds many restoration projects. ${ }^{286}$ But in the absence of a rigorous effort to relate individual consultation outcomes to broader species trends, it is very difficult to know if the services are doing enough. ${ }^{287}$ And even if their efforts are producing positive trends, they are doing so by shifting to a subset of regulated projects - and, to a large extent, to the taxpayer - the burden of compensating for the many projects that escape the adverse modification prohibition.

If critical habitat protection is to assume greater significance, and if the gap between the services' implementation approach and statutory requirements is to be reduced, if not closed, the services and the courts must resolve this regulatory thresholds dilemma. They need not throw out everything about their existing approaches, for, as discussed above, they already are accomplishing quite a lot through their attempts to minimize each project's impacts. But they do need a few additional tools. The discussion below explains two promising possibilities. ${ }^{288}$

\section{Low thresholds and off-site mitigation}

While reviewing biological opinions, I found very few uses of off-site mitigation to compensate for on-site environmental impacts. ${ }^{289}$ If a project was going to degrade location A, the services generally imposed conditions to minimize (and sometimes eliminate) that

\footnotetext{
${ }^{286}$ See supra Table 2.

${ }^{287}$ See generally Rose, supra note 13, at 279 ("In focusing on individual actors' behavior, [behavior-based] measures were inattentive to the fact that even small amounts can add up.").

${ }^{288}$ A third possibility, which merits more extensive discussion than this article has space to provide, would be to integrate the services' efforts with other agencies' initiatives to address major problems like climate change or urban sprawl. Such integration might blunt common criticisms of the ESA, which sometimes suggest that the statute pits species protection against all other important social values. See, e.g., MANn AND PLUmmer, supra note 231, at 213 (" $[\mathrm{I}] \mathrm{t}$ is not possible to (protect species) and simultaneously ensure that good housing is available to everyone. Or good health care, for that matter, or a good education."). But while numerous scholars have emphasized the importance of such integration, the challenges of achieving it are substantial. See, e.g., James E. Krier and Mark Brownstein, On Integrated Pollution Control, 22 ENVTL. L. 119, 121-22 (1991) (explaining some of the practical considerations that led EPA to reject an integrated regulatory approach); Ruhl and Salzman, supra note 10 , at $70-71$.

${ }^{289}$ In the pool of 138 biological opinions that I closely reviewed, only a handful called for or referred to off-site mitigation measures. Those measures might have been prescribed in other documents - some biological opinions refer to conditions set forth in the action agency's biological assessment—but the rarity of references to off-site mitigation demonstrates that it is not common practice.
} 
degradation at location $\mathrm{A}$, but they did not require compensatory restoration work at location $\mathrm{B}$. Individual biologists did mention using this approach, but not extensively, and in their experience it was relatively new. ${ }^{290}$ In taking this approach, they were working with little direction or guidance. The services' joint consultation regulations say nothing about off-site mitigation, and their consultation handbook does not prescribe any such approach, let alone provide guidance for its implementation.

This is a lukewarm embrace of a practice now standard in many other areas of environmental law. ${ }^{291}$ Off-site mitigation is now a core part of wetlands protection. ${ }^{292}$ Offset programs, under which new pollution sources in non-attainment areas must pay existing sources to reduce their emissions, are specifically prescribed by the Clean Air Act. ${ }^{293}$ Off-site mitigation is even common practice in "habitat conservation plans" prepared pursuant to ESA section $10 .{ }^{294}$ In the view of many environmental scholars, these trading regimes are both economically and environmentally preferable to traditional regulatory approaches, and, according to some commentators, their emergence has been a crucially important step in the maturation of environmental law. ${ }^{295}$

Despite their growing prevalence, these trading approaches have their detractors. Critics have argued that in practice, off-site mitigation often has meant trading ecologically valuable natural systems for dysfunctional artificial substitutes. ${ }^{296}$ More broadly, critics argue that in

${ }^{290}$ E.g. NMFS Biologist Interview, November 22, 2010.

${ }^{291}$ See generally James Salzman and J.B. Ruhl, Currencies and the Commodification of Environmental Law, 53 STAN. L. REV. 607 (2000).

292 See id. at $650-51$.

29342 U.S.C. $§ 7503$ (c) (2006).

${ }^{294}$ See Salzman and Ruhl, supra note 291, at 648-49.

295 See, e.g., Bruce A. Ackerman \& Richard B. Stewart, Reforming Environmental Law, 37 STAN. L. REV. 1333, 1334-40 (1985); Salzman and Ruhl, supra note 291, at 609-11 (citing some of the voluminous literature on this subject).

${ }^{296}$ See Fred Bosselman, Swamp Swaps: The “Second Nature” of Wetlands, 39 ENVTL. L. 577,583 (2009) (summarizing critiques); Committee on Mitigating Wetland Losses, National Research CounCiL, 
practice, trading schemes are excessively complex and often involve trading real environmental degradation for fictional environmental gains. ${ }^{297}$ And even though trading programs are designed to reduce opposition to environmental regulation, they rarely eliminate it. Even with mitigation programs in place, regulated entities have still chafed at the extent of environmental regulation and have taken their frustrations as far as the Supreme Court, with some success. ${ }^{298}$

The critics raise important points, but the critical habitat experience shows that in the absence of an offsite trading program, many small environmental harms will simply escape regulatory coverage. If a project has significant non-environmental social utility-if, to use an example cited by one NMFS biologist, it is a small repair that will allow an important existing roadway to remain functional ${ }^{299}$ - but will unavoidably harm a small habitat area, a biologist must choose between enforcing the letter of the statute at significant social (and, potentially, political) cost or, alternatively, allowing habitat degradation to proceed without mitigation. It is not hard to imagine what most biologists will choose. Yet those same impacts might be cheaply mitigated, perhaps by contributing to a dam removal, wetlands restoration project, or purchase of environmental water rights elsewhere on the same river, and the action agency and project proponent might be willing to support those efforts as a condition for proceeding with the project. Designing such an off-site mitigation program is no easy task; the extensive critiques of existing programs amply demonstrate that mitigation trading programs require careful design and

COMPENSATING FOR WeTLAND LOSSES UNDER THE ClEAN WATER ACt 1-10 (2001) (summarizing problems with then-prevalent mitigation approaches).

${ }^{297}$ These concerns have been particularly salient in the debate over climate change mitigation methods. See, e.g., Nick Davies, The Inconvenient Truth about the Carbon Offset Industry, THE GuARDIAN, June 16, 2007, available at $\mathrm{http} / / / \mathrm{www}$.guardian.co.uk/environment/2007/jun/16/climatechange.climatechange. See also Salzman and Ruhl, supra note 291 (discussing some of the inherent challenges of creating trading systems).

${ }_{298}$ See Rapanos v. United States, 547 U.S. 715, 722 (2006) (describing, with obvious consternation at its scope, the federal regulatory program for wetlands).

${ }^{299}$ NMFS Biologist Interview, November 22, 2010. 
oversight. ${ }^{300}$ But for critical habitat protection, even modestly effective mitigation efforts should improve upon the status quo.

\section{Planning and standardized threshold-setting}

Another distinctive feature of the services' current approach is its ad-hoc, project-byproject selection of regulatory thresholds. As of this writing, the services have no regulation or even guidance that defines the line between adverse modification and permissible habitat degradation. Nor do they have any process, outside of individual consultations, for drawing that distinction. Agency biologists do discuss the question; several biologists told me that these questions are often debated in what one described as "geeky section 7 coordinator circles.",301 But none of the biologists felt that the services had resolved the issue, and opinions varied about what the standard should be. ${ }^{302}$ To add to the challenge, current agency regulations and guidance place partial blinders on biologists seeking to resolve this question. When conducting consultations, the services may not consider the cumulative impacts of other future projects also subject to consultation. ${ }^{303}$

That approach places field biologists in difficult positions. To determine whether an individual project contributes significantly to a larger problem, a field biologist would need to understand the impacts of the full set of activities likely to affect the species. For a biologist

\footnotetext{
${ }^{300}$ See, e.g., Salzman and Ruhl, supra note 291 (exploring the challenges of developing such programs).

${ }^{301}$ FWS Biologist Interview, December 21, 2010; see FWS Biologist Interview, January 12, 2011 ("section 7 people talk about this endlessly"); but see FWS Biologist Interview, November 4, 2010 (contrasting discussions of jeopardy, which she felt had led to better understanding of the concept, with less-developed discussions of adverse modification).

${ }^{302}$ Compare FWS Biologist Interview, January 12, 2011 (asserting that Congress intended the jeopardy and adverse modification standards to be the same) with Email from NMFS Biologist, October 15, 2010 ("I believe the bar for an adverse mod/destruction determination is much lower than a jeopardy determination."); FWS biologist interview, December 7, 2010 (asserting that "ad mod could be a much lighter trigger" and that it is "sort of problematic" that adverse modification and jeopardy are typically treated as equivalent).

${ }^{303}$ CONSULTATION HANDBOOK, supra note 72, at 4-31 (excluding future federal actions and any other action that is not "reasonably certain to occur" from the analysis); see Rohlf, supra note 100, at 156-57 (criticizing this approach as "virtually unworkable").
} 
swamped with consultation deadlines and struggling to get through the day's work, ${ }^{304}$ stepping back and performing that kind of broader analysis is likely to be impossible, particularly if agency guidance tells that biologist to ignore many future projects. ${ }^{305}$ In the absence of that broader perspective, and without the backing of a centralized policy on cumulative impacts, a decision to impose a prohibitive regulatory regime on a project with seemingly minor impacts will be very difficult to make. ${ }^{306}$ Occasionally agency biologists will be willing to do so, but it should be no surprise if often they are not.

Again, other environmental laws offer better alternatives, with the most robust example coming from air quality planning. Every year, air quality planners in non-attainment zones across the country confront a challenge like the habitat degradation problems faced the FWS and NMFS. $^{307}$ Rarely is regional air quality determined by the emissions from a single facility. Instead, air pollution problems typically derive from the collective emissions of many factories, power plants, roads, and other sources. ${ }^{308}$ Those emissions often interact in complex and nonlinear ways. ${ }^{309}$ Consequently, determining on an ad-hoc, project-by-project basis what level of emissions should trigger regulation would be nearly impossible, and the Clean Air Act does not ask anyone to try. It instead compels states to develop "state implementation plans" that address all emission sources, and it only allows approval of plans that simulation models predict will

\footnotetext{
${ }^{304}$ See FWS biologists interview, November 3, 2010 (stating that the services are "barely keeping our heads above water with section 7 consultations").

${ }^{305}$ See CONSUlTATION HANDBOOK, supra note 72, at 4-31.

${ }^{306}$ See David M. Theobald et al., Ecological Support for Rural Land-Use Planning, 15 ECOLOGICAL APPLICATIONS 1906, 1909 (2005) (explaining the difficulty of finding changes to be significant when each proposed project will cause only a small change). Agency biologists readily acknowledged that adverse modification findings were not encouraged. See NMFS biologist interview, December 7, 2010 ("you write this, you're going to have to defend it and support it and come up with an alternative").

${ }^{307}$ Non-attainment zones are areas that do not comply with national ambient air quality standards. See 42 U.S.C. $§ 7501(2)$.

${ }^{308}$ See 42 U.S.C. 7408 (requiring ambient air quality standards for pollutants "the presence of which in the ambient air results from numerous or diverse mobile or stationary sources").

${ }^{309}$ See James D. Fine and Dave Owen, Technocracy and Democracy: Conflicts Between Models and Participation in Environmental Law and Planning, 56 HASTINGS L.J. 901, 914, 944-45 (2005) (describing mechanisms of ozone creation).
} 
attain the ultimate air quality goal. ${ }^{310}$ The contrast to the project-by-project section 7 approach is dramatic.

This comprehensive approach presents several obvious advantages. First, rather than addressing each individual action in an analytical vacuum, it gives planners an opportunity to consider the aggregate consequence of all of the actions threatening to cause environmental degradation. Second, it compels them to think through the implications of setting regulatory thresholds at a particular level. If those thresholds are set too high, and the modeling is reasonably accurate, ${ }^{311}$ the model will not predict attainment, and the planners must return to the drawing board. ${ }^{312}$ Third, that approach gives regulators opportunities to develop programs to compensate if they do choose to set regulatory thresholds that exempt some contributors. ${ }^{313}$ If regulators decide that regulating some low-level emitters is not worth the effort, they can change the stringency of other regulatory programs to compensate for that selective non-coverage. In short, rather than addressing each project's incremental impacts in an analytical vacuum, that approach compels regulators to ask "how are we going to fit our approach to incremental harms into a larger strategy for achieving the outcome we want?"314

${ }^{310} 42$ U.S.C. 7410. For detailed descriptions of this approach, see Arnold W. Reitze, Jr., Air Quality Protection Using State Implementation Plans--Thirty-Seven Years of Increasing Complexity, 15 VILL. ENVTL. L.J. 209, 226-41 (2004); Fine and Owen, supra note 309, at 949-62. These SIPs are not the Clean Air Act's exclusive regulatory program; it also relies extensively on technology-based controls.

${ }^{311}$ Sometimes it is, and sometimes it is not. See Fine and Owen, supra note 309, at 949-62 (describing an unsuccessful monitoring exercise); Dave Owen, Probabilities, Planning Failures, and Environmental Law, 84 TULANE L. REV. 265, 282 n.93 (2009) (quoting EPA employees describing some of their models as very accurate).

${ }^{312}$ See Fine and Owen, supra note 309, at 914 (noting that the Clean Air Act requires attainment demonstrations as a prerequisite to SIP approval).

${ }^{313}$ See Whitman v. Am. Trucking Ass'ns, 531 U.S. 457, 470 (2001) ("It is to the States that the CAA assigns initial and primary responsibility for deciding what emissions reductions will be required from which sources.").

${ }^{314}$ Many critics allege that this type of comprehensive planning is prone to manipulation and requires more information than regulators realistically can obtain. See, e.g., Reitze, supra note 310, at 357-58 (dismissing the SIP program as a "failure," largely because many areas remain in nonattainment); OLIVER O. HOUCK, THE TMDL PROGRAM: LAw, POLICY, AND IMPLEMENTATION 207 (1999) (“[O]ne would not wish the SIP program on one's worst enemy"). Both problems are clearly real, and the track record of these planning approaches includes many failures. See, e.g., Fine and Owen, supra note 309, at 956-957, 960-62 (discussing a planning process marked by misleading treatment of uncertainties and questionable tweaking of assumptions). But it also includes successes, 
Though the services may never develop an approach as intensive as the SIP process, planning processes already prescribed by other sections of the ESA provide useful starting points. First, ESA section 4 already prescribes recovery plans for listed species. ${ }^{315}$ That recovery planning creates an opportunity to develop regulatory thresholds and to integrate those thresholds into a broader strategy for recovery. ${ }^{316}$ Second, and more ambitiously, the services could integrate critical habitat protection into large-scale "habitat conservation plans" (HCPs) prepared pursuant to sections 9 and 10 of the ESA. ${ }^{317}$ These plans allow otherwise prohibited "takes" of endangered species so long as the entity responsible for the take is participating in a plan expected to provide a net benefit to the impacted species. ${ }^{318}$ The services could offer the same deal for projects causing small adverse changes to habitat: if the project proponent participates in a broader HCP that will create an overall improvement in habitat conditions, the services would not find adverse modification. ${ }^{319}$ Though implementing such an approach would be challenging, ${ }^{320}$ the benefits might be substantial. ${ }^{321}$ A coordinated conservation approach could provide much more conservation benefit than many isolated and partial minimization

and some regulators believe their planning approaches have worked reasonably well. See, e.g., Owen, supra note 311 , at 283 n.101 (noting that EPA employees involved in SIP planning viewed the process as reasonably successful)

31516 U.S.C. $§ 1533(f)(2006)$.

${ }^{316}$ That shift would significantly change recovery planning, which critics allege has traditionally involved vague plans and modest goals. See, e.g., Federico Cheever, The Road to Recovery: A New Way of Thinking about the Endangered Species Act, 26 ECOLOGY L.Q. 1 (1996).

${ }^{317}$ See 16 U.S.C. C 1539(a)(2)(A) (2006);

${ }^{318}$ See Ruhl and Salzman, supra note 291, at 648-49 (explaining the program).

${ }^{319}$ To be legally tenable, that approach would need to treat participation in the HCP as part of the "action" subject to consultation. I see nothing in the statute that precludes such an approach.

${ }^{320}$ HCPs have received mixed reviews in the environmental law literature. See Alejandro E. Camacho, Can Regulation Evolve? Lessons from a Case Study in Maladaptive Management, 55 UCLA L. REv. 293 (2007) (criticizing the program, but also summarizing arguments in its favor). But the more critical discussions still suggest that HCPs can be done well; Camacho, for example, criticizes the program primarily for being overly closed to public participation and scrutiny and because of an absence of monitoring and adaptation, but notes that HCPs prepared more openly appear to have produced better results. See id. at 318-19.

${ }^{321}$ The literature on the potential benefits of HCPs is extensive. See, e.g., Joseph L. Sax, Environmental Law at the Turn of the Century: A Reportorial Fragment, 88 CAL. L. REV. 2375, 2381 (2002) (explaining potential political benefits); Thompson, supra note 30, at 318-19 (describing potential benefits of HCPs, though also acknowledging that transaction costs have been substantial). 
efforts, ${ }^{322}$ and more extensive enforcement of the adverse modification prohibition could create an important incentive for participation in large-scale HCPs. ${ }^{323}$

\section{B. Praising the Complexity}

The preceding discussion suggests what may seem an odd hybrid of regulatory approaches. It would include elements of prohibitory regulation, negotiated feasibility-based standards, trading-based mitigation schemes, and planning-based approaches, all integrated into a system that combines slightly increased centralization with a continued reliance on project-byproject, location-specific regulatory controls. It may seem like an approach developed by indecisively ordering everything on the environmental regulatory menu, notwithstanding years of academic arguments asserting that one or a few of those tools is best. ${ }^{324}$ But the hybrid nature of the prescribed reforms reflects the services' need, in a world of flawed options, for a regulatory toolbox with multiple tools. ${ }^{325}$ But if a creative and pragmatic agency holds discretion to select from among a variety of approaches, the portfolio of regulatory approaches should be superior to any of its imperfect parts.

That need for regulatory portfolios leads to a broader point about regulating complicated environmental challenges. It is easy to look at our environmental law system, with its "great undigestible masses of statutes... interpreted by mounds of regulations, all densely packed with bizarre terms and opaque acronyms, ${ }^{, 326}$ and pine for some simplicity. The sometimes-painful,

\footnotetext{
${ }^{322}$ See Theodore C. Weber and William L. Allen, Beyond on-site mitigation: An integrated, multi-scale approach to environmental mitigation and stewardship for transportation projects, 96 LANDSCAPE AND URBAN PLANNING 240 (2010) (describing ways that a coordinated mitigation strategy can outperform site-by-site efforts).

${ }^{323}$ Landowner reluctance to participate has often been flagged as a challenge facing large-scale HCPs. See Thompson, supra note 30, at 318 .

${ }^{324}$ See, e.g., Ackerman and Stewart, supra note 295 (advocating trading schemes); Houck, supra note 280 (feasibility-based controls); Wood, supra note 48 (public trust protections).

${ }^{325}$ See generally Holly Doremus, A policy portfolio approach to biodiversity protection on private lands, 6 ENVTL. SCI. \& POLICY 217 (2003).

${ }^{326}$ Carol Rose, Rethinking Environmental Controls: Management Strategies for Common Resources, 1991 DUKE L.J. 1, 1; see Wood, supra note 48, at 57 . To be clear, Rose focuses on making sense of the "undigestible masses," not on developing a simpler regulatory scheme.
} 
often contentious history of implementing that system only increases the temptation. Surely, one might think, among those approaches (or waiting to be developed) is a better way, and surely many of the existing approaches are deeply flawed or obsolete and can simply be discarded. But the critical habitat experience suggests that such hopes, while perfectly understandable, may well be misplaced. A diversity of regulatory approaches will often be a strength rather than a weakness, for there are elements of wisdom in many of the regulatory approaches would-be reformers sometimes dismiss. And while changes and reforms will still be necessary for environmental law to take on its next generation of challenges, the critical habitat story suggests that some of the changes can be subtle. Rather than scrapping existing regulatory approaches and creating something entirely new, the best reforms may involve doing some modest tinkering with existing incentives and approaches, giving agencies a few new tools to use, and trusting, notwithstanding all the anti-governmental rhetoric of contemporary politics, that those agencies will have the creativity and commitment to put those tools to good use.

\section{CONCLUSION}

The listing of the polar bear as a threatened species and the subsequent designation of its critical habitat were not isolated events. Climate change is likely to lead to many other species listings, and dozens of species initially listed for other reasons also face climate change as a major threat. ${ }^{327}$ And climate change is just one of many major environmental impacts caused by

${ }^{327}$ For just a few of the many possible examples, see U.S. Fish and Wildlife Service, Determination of Endangered Status for the Georgia Pigtoe Mussel, Interrupted Rocksnail, and Rough Hornsnail and Designation of Critical Habitat, 75 Fed. Reg. 67512, 67523 (November 2, 2010) (identifying climate change as a threat); National Oceanic and Atmospheric Administration, Threatened Status for the Puget Sound/Georgia Basin Distinct Population Segments of Yelloweye and Canary Rockfish and Endangered Status for the Puget Sound/Georgia Basin Distinct Population Segment of Bocaccio Rockfish, 75 Fed. Reg. 22276, 22282 (April 28, 2010) (acknowledging climate change as a potentially major threat); National Oceanic and Atmospheric Administration, Threatened Status for Southern Distinct Population Segment of Eulachon, 75 Fed. Reg. 13012, 13015 (March 18, 2010) ("We also 
an accumulation of seemingly minor actions. ${ }^{328}$ The central regulatory challenge addressed by this Article is large and is continuing to grow.

Current regulatory approaches are only partially equipped to address that challenge. The services have taken substantial steps to address habitat degradation, and their efforts undermine critiques alleging that ESA implementation is characterized by rigid inflexibility or, alternatively, by regulatory capture. But the empirical record still indicates a substantial gap between statutory requirements and actual performance, and the gap is particularly acute where incremental degradation is occurring. That gap need not be quite so large; tools to address some of those tensions exist, and could be exploited with only modest adjustments to existing regulatory systems. The services, and any other regulator seeking to address incremental environmental degradation, can and should take advantage of those opportunities.

recognize that climate change impact on ocean conditions is likely the most serious threat to persistence of eulachon in all four sub-areas of the DPS.").

${ }^{328}$ See supra notes 10-13 and accompanying text. 